Article

\title{
Aquifer Drawdown and Recovery in the Northeast Groundwater Management Area, Wisconsin, USA: A Century of Groundwater Use
}

\author{
John A. Luczaj ${ }^{1, *}$, Julie Maas ${ }^{2}$, David J. Hart ${ }^{3}$ and Jonathan Odekirk ${ }^{1}$ \\ 1 Department of Natural \& Applied Sciences, University of Wisconsin-Green Bay, Green Bay, WI 54311, USA; \\ odie_odie_@hotmail.com \\ 2 NEW Water (Green Bay Metropolitan Sewerage District), Green Bay, WI 54302, USA; JMaas@newwater.us \\ 3 Wisconsin Geological \& Natural History Survey, Madison, WI 53705, USA; dave.hart@uwex.edu \\ * Correspondence: luczajj@uwgb.edu; Tel.: +1-920-465-5139
}

Academic Editors: Peiyue Li, Michael Schneider and Jesús Martínez-Frías

Received: 19 January 2017; Accepted: 28 February 2017; Published: 7 March 2017

\begin{abstract}
The Northeast Groundwater Management Area of Wisconsin, USA contains two major cones of depression in a confined sandstone aquifer. Each cone is centered near cities that have used groundwater for over 100 years. Near one of these cities (Green Bay), episodic changes in the development of groundwater and surface water resources during this period have resulted in major changes to the potentiometric surface. On two occasions, roughly 50 years apart, reductions in groundwater withdrawals have resulted from the construction of pipelines drawing surface water from Lake Michigan. In each case, rapid recovery of the potentiometric surface by as much as $70 \mathrm{~m}$ has occurred in the northern of the two pumping cones. The most recent switch occurred during 2006 and 2007 when eight communities stopped pumping groundwater, reducing daily withdrawals by approximately 46.37 million liters. The rate of water level recovery has diminished in some areas, with a return to a flowing artesian state for some municipal and residential wells. Although the northern portion of the groundwater management area has returned to a sustainable condition in the confined aquifer, the portion with the southern cone of depression remains in a state of prolonged drawdown.
\end{abstract}

Keywords: Wisconsin; groundwater management; recovery; potentiometric surface; drawdown; Cambrian; sandstone

\section{Introduction}

Aquifer depletion from extensive groundwater withdrawal is a widespread problem affecting broad regions of the world [1,2]. Adequate long-term monitoring of aquifer water levels is a critical component necessary for risk management of water resources [2]. While many aquifers show accelerating rates of depletion [1], few aquifers have shown large-scale water level recovery due to improved management changes or alternative water supplies (e.g., [3,4]).

Aquifer drawdown and recovery are a function of the interplay between a society's use of groundwater and its responses to resource sustainability issues. As such, drawdown and recovery are not the whole story by themselves. In the United States, while hydrogeologists and engineers play an important role in making recommendations, they do not make short-term or long-term decisions or implement resource use strategies. In most cases, local democratically elected officials are responsible for such decisions. When disputes arise, resolutions are often made in courts of law. 


\subsection{Water Resources in Wisconsin}

The state of Wisconsin, USA, is located in the western Great Lakes region of North America (Figure 1) and has abundant supplies of surface water and fresh groundwater [5]. Few areas have faced water quantity limitations, but expanding water use, coupled with long-term aquifer drawdown, has resulted in noteworthy water supply challenges.

About $88 \%$ of water withdrawal in Wisconsin is from surface water supplies, with the remaining $12 \%$ from groundwater [6]. However, the majority (90\%) of surface water use was for cooling water, so the amount of non-cooling groundwater use exceeds non-cooling surface water use statewide [7]. Statewide, 800,000 small private wells, plus an additional 11,000 high capacity wells serve industry, municipal, and agricultural purposes [6,8]. Land use in the study area is characterized by a mix of urban development, small rural communities, and industries, including manufacturing, dairy production, and agricultural field crops [9].

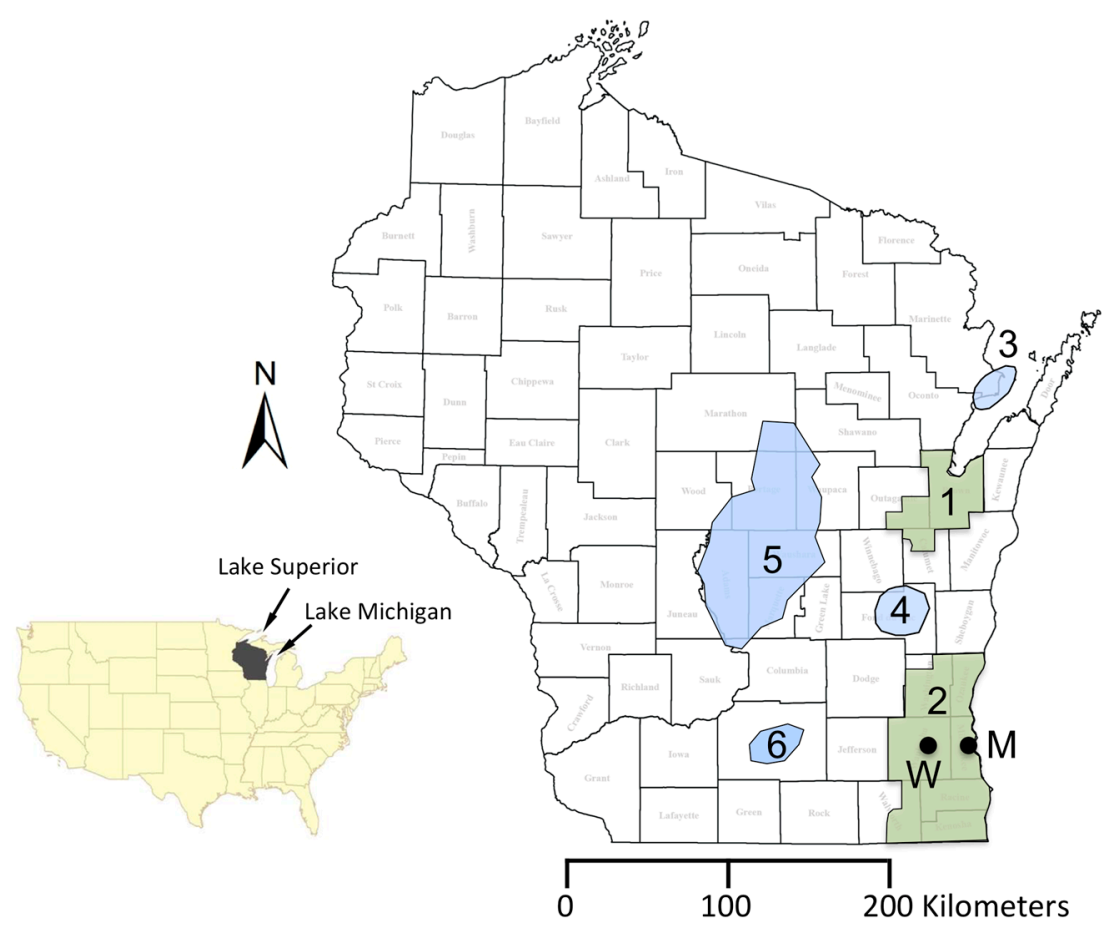

Figure 1. Map showing the location of Wisconsin counties with formally defined groundwater management areas of the state highlighted in green. Additional areas with significant drawdown are shown in blue. Inset map shows the location of Wisconsin in the lower 48 contiguous United States. Numbered regions are as follows: (1) Northeast Groundwater Management Area (Northeast GMA); (2) Southeast Groundwater Management Area; (3) area of drawdown in Marinette County; (4) area of declining water levels in Fond du Lac County; (5) area of declining water levels in Dane County; and (6) an area impacted by irrigation drawdowns in the Central Sands region [5,10,11]. Letter designations for cities mentioned in the text are Waukesha (W) and Milwaukee (M).

\subsection{Sustainability and Groundwater Management Areas in Wisconsin}

Groundwater sustainability has been a topic of concern in the region for over a century. The earliest known use of groundwater from the confined sandstone aquifer in the Northeast Groundwater Management Area (GMA) occurred during the 1880s in the cities of Appleton, Kaukauna, and De Pere [12,13]. Work during the middle of the 20th century addressed groundwater quantity issues [13-15] and presented an analysis of the first transition from groundwater to surface water by the City of Green Bay in 1957 [13]. In the late 20th century, a more comprehensive hydrogeologic framework was established that led to several numerical models for the confined sandstone aquifer in 
northeastern Wisconsin [16-21]. In the last decade, research in and near the Northeast GMA has focused on bedrock mapping [22,23], structural mapping [22,24], and water age, quality, and quantity [25-29].

In response to potential unsustainable groundwater use, Wisconsin's Groundwater Protection Act, 2003 Wisconsin Act 310 [30], expanded the state's authority to consider environmental impacts of high capacity wells and instituted a framework for addressing water quantity issues in specific geographic areas of the state. The legislation directed the Wisconsin Department of Natural Resources (WDNR) to establish two GMAs in response to aquifer drawdowns. The two initial GMAs were established in northeastern and southeastern Wisconsin (Figures 1 and 2) in regions that obtain much of their groundwater from a confined, eastward dipping lower Paleozoic sandstone aquifer. The GMA boundaries were designated in or near areas in which "the groundwater potentiometric surface has been reduced 150 feet $(45.7 \mathrm{~m})$ or more from the level at which the potentiometric surface would be if no groundwater had been pumped" [30]. Future GMAs could be defined by using other criteria such as change in flow or impacts to surface waters rather than change in head, depending on conditions in those areas.

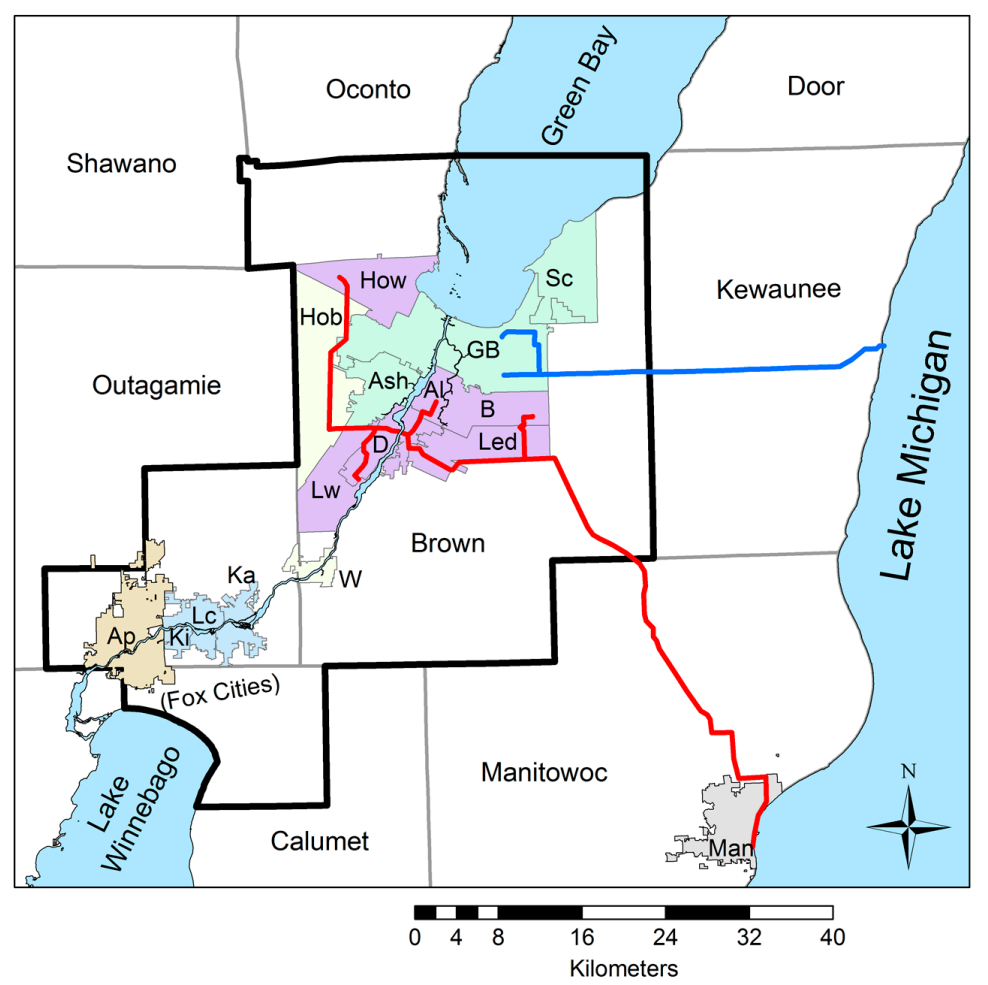

Figure 2. Map of the Northeast GMA (bold black line) illustrating the location of relevant municipalities and surface water pipelines described in this paper. In the region of central Brown County, municipalities served by the Green Bay Water Utility's pipeline (blue) are Green Bay (GB), Ashwaubenon (Ash) and Scott (Sc), Hobart (Hob), and Wrightstown (W). Communities served by the Central Brown County Water Authority's pipeline (red) include Bellevue (B), Allouez (Al), Ledgeview (Led), De Pere (D), Lawrence (Lw), and Howard (How). Areas to the south include the "Fox Cities" of Kimberly (Ki), Little Chute (Lc), and Kaukauna (Ka) and Appleton (Ap). The Fox River connects Lake Winnebago to Green Bay.

\subsection{Purpose of the Research}

This article presents the history of the Northeast GMA in Wisconsin (Figure 2), with a focus on recent water level changes since 2005. Figure 3 shows a timeline of major changes in the Northeast GMA that can help the reader place historical events into a broader context. In this article, we present a history of groundwater management and corresponding aquifer water level changes in a groundwater 
management area in the central United States. We provide this example as an illustration of how this particular society dealt with changes in sustainability of its groundwater resources over the course of more than a century.

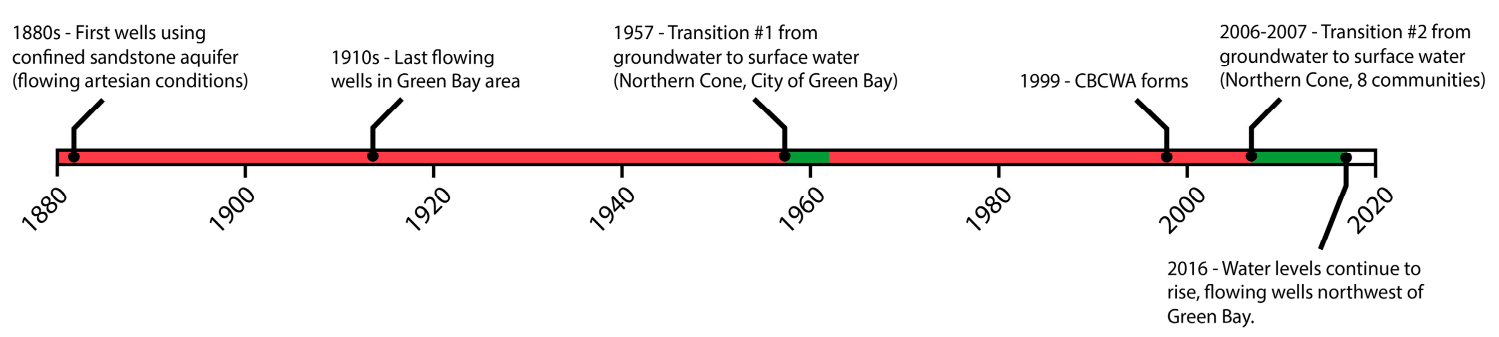

Figure 3. Timeline of major events in the Northeast Groundwater Management Area. Red periods indicate intervals of aquifer drawdown, while green periods indicate periods of aquifer recovery.

\section{Geologic and Geographic Setting}

\subsection{General Geography of Eastern Wisconsin}

Wisconsin lies at the junction of the Superior uplands in the north, and several subsections of the Central Lowlands Province in the United States. The region has a humid continental climate and cold winters, with mean annual precipitation (liquid equivalent) between 75 and $84 \mathrm{~cm}$ [31]. Its population is just under 5.7 million people [32], with the largest density in the eastern and southeastern portions of the state. The largest municipalities in the Northeast GMA include Green Bay and surrounding communities in central Brown County, as well as the "Fox Cities" region from Appleton to Kaukauna along the Fox River in Outagamie County (Figure 2).

\subsection{Geology and Hydrostratigraphy of Eastern Wisconsin}

The bedrock geology of eastern Wisconsin consists of a complex array of eroded Precambrian crystalline rocks, overlain by a sequence of Paleozoic marine rocks that are as much as $700 \mathrm{~m}$ thick (Figure 4). These units dip eastward away from central Wisconsin, toward the Michigan basin in the east (Figure $4 \mathrm{~b}$ ). Overlying these rocks are Pleistocene glacial, glaciofluvial, and glaciolacustrine sediments that range in thickness from $0 \mathrm{~m}$ to over $100 \mathrm{~m}$ and are important confining layers in parts of the region [33,34]. Table 1, Figure 4, and Supplementary File S3 present a generalized hydrostratigraphy and structure for northeastern Wisconsin. Additional details are available in Krohelski [16], Luczaj [24], and Luczaj et al. [35].

The Paleozoic strata in the Northeast GMA can be separated into three hydrostratigraphic groups. The lowermost groups include the Cambrian-Ordovician sandstone and dolostone units that are informally known as the "confined sandstone aquifer" in the region. The Cambrian units are generally $120 \mathrm{~m}$ thick high conductivity ultramature quartz sandstone, with lesser amounts of shale and dolomitic and glauconitic sandstone. The overlying Prairie du Chien and Ancell groups constitute the remainder of the confined Cambrian-Ordovician sandstone aquifer. The Ancell Group is dominated by the St. Peter Sandstone, an exceptionally mature quartz sandstone that fills a network of unconformity generated paleovalleys up to $100 \mathrm{~m}$ deep $[17,24,36]$. Together, this $\sim 180 \mathrm{~m}$ sequence of Cambrian-Ordovician rocks is treated as one confined aquifer.

The Ordovician Sinnipee Group (aka Trenton-Black River Group) and the Late Ordovician Maquoketa Shale are two significant low permeability units overlie the Cambrian-Ordovician sandstone aquifer and act as regional confining layers and are about 160 to $210 \mathrm{~m}$ thick. The Sinnipee Group is a uniform $61 \mathrm{~m}$ thick and is mainly tight dolostone with a minor shale layer in the middle. The Maquoketa Shale is only present in the eastern half of the GMA (Figure 4). The uppermost Paleozoic bedrock unit present in the region is a set of four Silurian dolostone formations that are typically treated as a single unconfined karst aquifer $[9,24]$. The units range in thickness from a few 
meters near parts of the Niagara Escarpment to nearly $150 \mathrm{~m}$ thick in the eastern part of the GMA. Pleistocene glacial, glaciofluvial, and glaciolacustrine sediments are spatially variable in thickness and hydraulic conductivity, but they typically act as important confining layers in the Northeast GMA because of their clay-rich characteristics $[16,18,34,37]$.

It is important to note that the confined sandstone aquifer is not in hydrologic communication with surface water bodies such as the Fox River, Lake Winnebago, or Green Bay (Figure 2) because the recharge zone for the sandstone aquifer is located to west, and the upper Ordovician bedrock units and the Pleistocene sediments act as effective confining units across the Northeastern GMA. This is corroborated by ${ }^{14} \mathrm{C}$ dating, noble gas chemistry, and stable isotopes suggesting recharge by subglacial meltwater from the Green Bay Lobe of the Laurentide Ice Sheet between about 12,000 and 25,000 years ago [27,29].

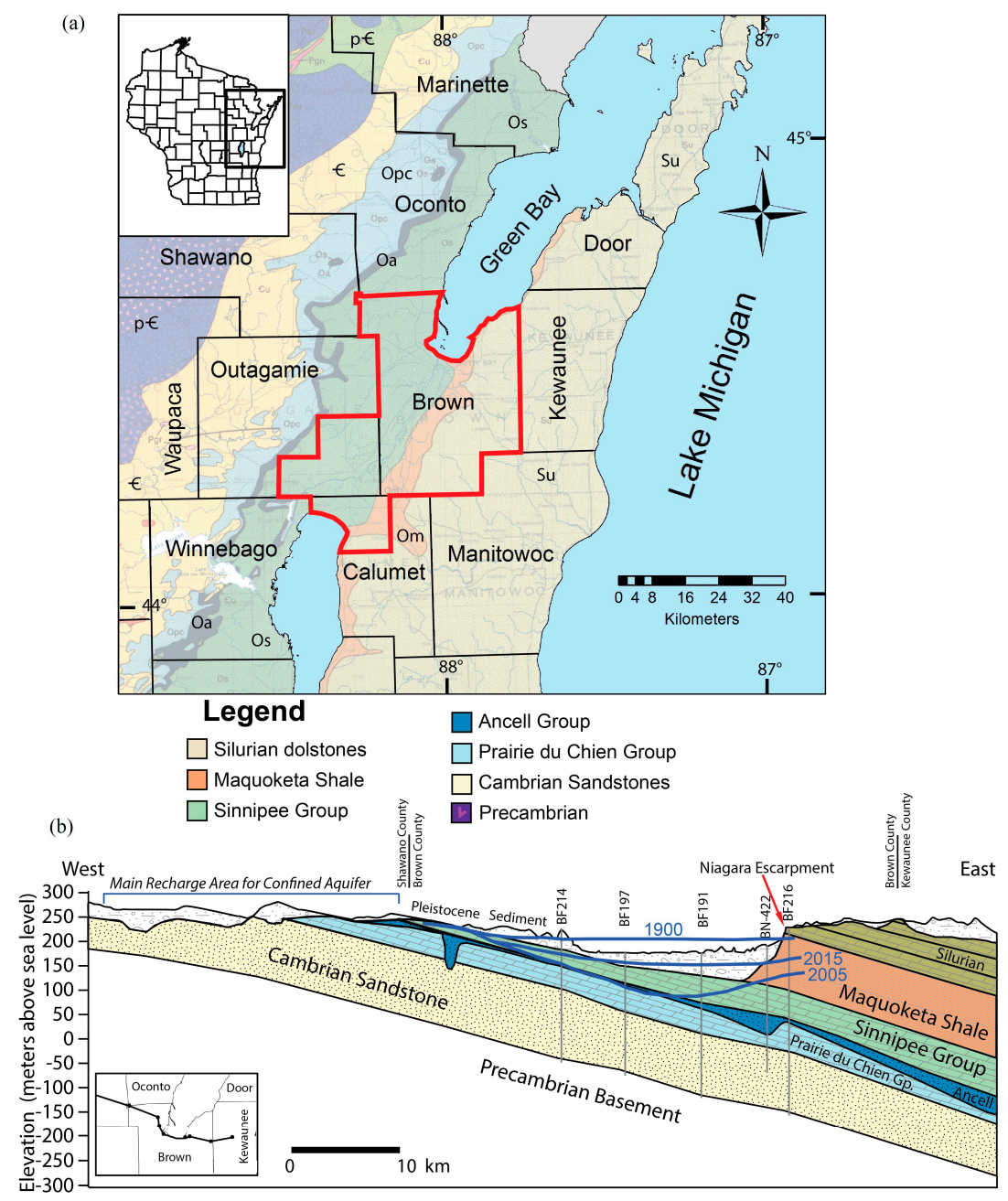

Figure 4. Geology of northeastern Wisconsin. (a) Bedrock geologic map with the northeast GMA outlined in red. Names indicate counties. Inset map shows the location in the state of Wisconsin, USA. Base map after Mudrey et al. [38] shows the following units: $p \in \in$ = Precambrian, $\mathrm{E}=$ Cambrian sandstones, Opc $=$ Ordovician Prairie du Chien Group, Oa = Ordovician Ancell Group, Os = Ordovician Sinnipee Group, Om = Ordovician Maquoketa-Neda formations, and Su = Silurian dolostones; (b) West to east cross section through portions of Shawano, Brown, and Kewaunee counties, Wisconsin [35]. Paleozoic strata typically dip southeastward between about 5 and $7.5 \mathrm{~m} / \mathrm{km}$ toward the ancestral Michigan basin. Vertical lines with labels indicate Wisconsin Unique Well Numbers (WUWN) for wells in the Green Bay region of Brown County. Blue lines with years show confined aquifer potentiometric levels for predevelopment (ca. 1900), 2005, and 2015. Vertical exaggeration is 45 times. 
Table 1. General hydrostratigraphy within the Northeast Groundwater Management Area of Wisconsin (after $[5,16,19,21,25,26])$.

\begin{tabular}{|c|c|c|c|c|}
\hline Geolog & ic Age & $\begin{array}{c}\text { Geologic Unit } \\
\text { (Thickness, Meters) }\end{array}$ & Lithology & Hydrostratigraphic Unit \\
\hline Cenozoic & $\begin{array}{l}\text { Quaternary } \\
\text { (Pleistocene) }\end{array}$ & $\begin{array}{l}\text { Unconsolidated } \\
\text { deposits }(0-60 \mathrm{~m}) \\
\text { Locally > } 100 \mathrm{~m}\end{array}$ & $\begin{array}{l}\text { Lacustrine silt and clay, } \\
\text { glacial till, fluvial sand and } \\
\text { gravel, and other deposits. }\end{array}$ & $\begin{array}{l}\text { Local unconfined aquifer } \\
\text { (sand and gravel; } \\
\mathrm{Kh}=4.1 \times 10^{-3} \mathrm{~cm} / \mathrm{s} \text { ) or } \\
\text { regional confining unit } \\
\text { (lacustrine clays and glacial till; } \\
\mathrm{Kv}=2.5 \times 10^{-6} \mathrm{~cm} / \mathrm{s} \text { ) }\end{array}$ \\
\hline \multirow{8}{*}{ Paleozoic } & Silurian & $\begin{array}{l}\text { Undifferentiated } \\
\qquad(0-150 \mathrm{~m})\end{array}$ & $\begin{array}{l}\text { Dolostone; fractured and } \\
\text { karsted in many locations. }\end{array}$ & $\begin{array}{l}\text { Upper Aquifer; Karsted in } \\
\text { many locations of } \\
\text { northeastern Wisconsin. } \\
\left(\mathrm{Kh}=3.4 \times 10^{-3} \mathrm{~cm} / \mathrm{s}\right)\end{array}$ \\
\hline & \multirow{4}{*}{ Ordovician } & $\begin{array}{l}\text { Maquoketa Formation } \\
\qquad(0-150 \mathrm{~m})\end{array}$ & $\begin{array}{l}\text { Shale, dolomitic shale, } \\
\text { and dolomite. }\end{array}$ & \multirow{2}{*}{$\begin{array}{l}\text { Confining Units; Sinnipee Group } \\
\text { Carbonates are locally used as } \\
\text { aquifers for domestic use. } \\
\left(\mathrm{Kv}=1.2 \times 10^{-8} \mathrm{~cm} / \mathrm{s}\right)\end{array}$} \\
\hline & & $\begin{array}{l}\text { Sinnipee Group } \\
(120 \mathrm{~m})\end{array}$ & $\begin{array}{l}\text { Dolostone with } \\
\text { some shale. }\end{array}$ & \\
\hline & & $\begin{array}{l}\text { Ancell Group } \\
\quad(0-100 \mathrm{~m})\end{array}$ & $\begin{array}{l}\text { Silty sandstone, fine- to } \\
\text { medium-grained } \\
\text { sandstone, sandy shale. } \\
\text { Fills paleovalleys. }\end{array}$ & $\begin{array}{l}\text { Upper Unit of the Confined } \\
\text { Sandstone Aquifer } \\
\left(\mathrm{Kh}=1.7 \times 10^{-3} \mathrm{~cm} / \mathrm{s}\right)\end{array}$ \\
\hline & & $\begin{array}{l}\text { Prairie du Chien } \\
\text { Group }(0-60 \mathrm{~m})\end{array}$ & $\begin{array}{l}\text { Dolostone with varying } \\
\text { amounts of oolitic chert } \\
\text { and minor } \\
\text { interbedded sandstone. }\end{array}$ & $\begin{array}{l}\text { Generally an aquitard relative to } \\
\text { the adjacent sandstones in eastern } \\
\text { Wisconsin, but locally an aquifer } \\
\text { for domestic use. }\end{array}$ \\
\hline & \multirow{3}{*}{ Cambrian } & $\begin{array}{l}\text { Trempealeau Group } \\
\qquad(0-15 \mathrm{~m})\end{array}$ & $\begin{array}{l}\text { Fine- to medium-grained } \\
\text { sandstone with some silty } \\
\text { glauconitic dolomite. }\end{array}$ & \multirow{3}{*}{$\begin{array}{l}\text { Lower Unit of the Confined } \\
\text { Sandstone Aquifer } \\
\left(\mathrm{Kh}=5.3 \times 10^{-4} \mathrm{~cm} / \mathrm{s} ;\right. \\
\text { up to } \mathrm{Kh}=2.9 \times 10^{-3} \mathrm{~cm} / \mathrm{s} \text { for } \\
\text { the Elk Mound Group) }\end{array}$} \\
\hline & & $\begin{array}{l}\text { Tunnel City Group } \\
\quad(30-46 \mathrm{~m})\end{array}$ & $\begin{array}{l}\text { Fine- to medium-grained } \\
\text { sandstone, silty sandstone } \\
\text { to sandy dolomite. } \\
\text { Abundant glauconite } \\
\text { commonly observed. }\end{array}$ & \\
\hline & & $\begin{array}{l}\text { Elk Mound Group } \\
\quad(75-90 \mathrm{~m})\end{array}$ & $\begin{array}{l}\text { Very-fine to } \\
\text { coarse-grained sandstone. }\end{array}$ & \\
\hline Precambrian & Precambrian & Undifferentiated & $\begin{array}{l}\text { Crystalline rock, } \\
\text { predominantly red granite, } \\
\text { contains igneous and } \\
\text { metamorphic rock. } \\
\text { Limited sedimentary rocks } \\
\text { (sandstone, dolostone) }\end{array}$ & $\begin{array}{l}\text { Yields little to no water in many } \\
\text { cases. Not used as an aquifer in } \\
\text { the Northeast GMA. }\end{array}$ \\
\hline
\end{tabular}

\section{Methods}

Existing publications, available digital records, historic paper records, and direct contact of high capacity well operators were used to compile the history of the Northeast GMA in Wisconsin. Pumping estimates and water levels were made only for the confined sandstone aquifer. An analysis for Silurian or Pleistocene aquifers is beyond the scope of this article.

Recent pumping data through 2014 were obtained from WDNR records [39]. Estimates for residential water use from the deep aquifer by domestic self-supplied wells was made using methodology defined by Maas [26], along with a WDNR database [40].

Long-term records of water levels include observation wells monitored by the Wisconsin Geological \& Natural History Survey (WGNHS) and the United States Geological Survey (USGS) (e.g., [41]), and static water levels from municipal well operators. High-quality data from WGNHS and USGS are reported to the nearest $\sim 3 \mathrm{~mm}$. Complete or partial records of static water levels (SWLs) were compiled for 17 municipalities in or near the Northeast GMA (File S2). Most municipal well 
water levels obtained using compressed air lines and pressure transducers reported water levels with a precision of $0.3 \mathrm{~m}$ and are considered are accurate to $\pm 3 \mathrm{~m}$ [42]. Other municipal wells had more precise readings from pressure transducers or other equipment, with precisions of about $\pm 0.08 \mathrm{~m}$. Some municipal water level data were obtained from the WDNR database of static water level data for municipal well operators $[43,44]$.

Contour maps for 1949, 1957, and 1960 were traced from existing publications and converted to standard international units. Contour maps for 1990 to 2015 were constructed in ArcMap 10.3 (ESRI, Redlands, CA, USA), using ordinary kriging and inverse distance weighting techniques and then traced in Adobe Illustrator (Adobe Systems, San Jose, CA, USA). Overall uncertainties for calculated water level elevations are estimated to be $\pm 2-3 \mathrm{~m}$. A complete set of contour maps is available in Supplementary File S1.

\section{Early History of the Northeastern Wisconsin Groundwater Management Area (Predevelopment through Year 1998)}

The history of the Northeast GMA is split into two major time periods. An early period includes predevelopment (late 19th century) through about the year 1998. Details from this period are available through a few key scientific publications and other sources that detail major changes in water use due to population and industrial growth, as well as changing water supply sources. The second time period includes the turn of the 21st century to the present and is the focus of this article (Section 5).

\subsection{Predevelopment and Early Development Conditions of the Confined Sandstone Aquifer}

Although the formal delineation of the Northeast GMA was made only in 2003, the confined sandstone aquifer in this region has been extensively used as a potable water source for well over a century. The earliest known use of groundwater from the confined sandstone aquifer in the Northeast GMA occurred during the 1880s in the cities of Appleton, Kaukauna, and De Pere [12-14]. Over a century ago, flowing artesian conditions for wells penetrating the confined sandstone aquifer were reported from many areas in eastern Wisconsin (Figures 5 and 6a), from the Milwaukee region in the southeast, all the way north to the Michigan border at Marinette [12]. In what is now the Northeast GMA, the initial hydraulic head of the wells reached $27.4 \mathrm{~m}$ above ground level in De Pere and $29.6 \mathrm{~m}$ above ground level in Green Bay. These were the strongest artesian flows observed in northeastern Wisconsin, although parts of southeastern Wisconsin had hydraulic head levels that reached at least $32.6 \mathrm{~m}$ above ground level.

In West De Pere, for example, the water pressures $(275.8 \mathrm{kPa})$ were sufficient to convey water across the city distribution system for domestic and city uses and for fire protection between 1886 and 1905, even for two-story buildings [12]. Initial capacity of the individual flowing artesian wells in Green Bay and De Pere was about 3.78 ML/day. Although water level data are sparse for this period of time, Figure 6a shows a regional contour map of the potentiometric surface in the confined sandstone aquifer ca. 1900, constructed using data from [12].

By 1910, average daily pumping from the eight wells in the City of Green Bay was about 4.94 million liters. By 1915, pumping and leakage had decreased hydraulic heads to only $3.7 \mathrm{~m}$ in De Pere and $2.7 \mathrm{~m}$ above ground level in Green Bay. In De Pere, pumping plants and storage reservoirs were added as artesian pressures declined. At this point in time, at least 24.4 to $26.8 \mathrm{~m}$ of drawdown had already occurred in central Brown County.

In the southern portion of the GMA (i.e., near the "Fox Cities" region), flowing wells were also common in the early 20th century, with hydraulic heads as much as $10.7 \mathrm{~m}$ above ground level in Kaukauna [12]. While the confined sandstone aquifer was sufficient to develop municipal water supplies for Kimberly, Kaukauna, and Little Chute, groundwater supply was apparently insufficient for the city of Appleton, which had already changed its water supply to the Fox River by 1915.

Industrial development in the Fox River Region during the early 20th century resulted in increasing population and industrial demand for water. By the late 1940s, water levels had been 
lowered dramatically (Figure 6b), and by the early 1950s, water quantity problems were a concern limiting growth in Green Bay [45]. By the mid-1950s, water levels had declined substantially from predevelopment conditions in central Brown County, as well as in the Fox Cities region in in the southern portion of the GMA. Drescher [14], LeRoux [15], and Knowles [13] describe the hydraulic conditions during the 1950s in the confined sandstone aquifer in Outagamie County and central Brown County. By 1957, net drawdown in the central Brown County region was approximately $126 \mathrm{~m}$ from predevelopment conditions, with the potentiometric surface elevation in the center of Green Bay at $78 \mathrm{~m}$ above sea level [13] (Figure 6c).

Less is known at this time about the drawdown near the Fox Cities in southeastern Outagamie County, as no clear cone of depression had been fully mapped in the southern part of the GMA. However, a comparison of data from Weidman and Schultz [12] and LeRoux [15] suggest drawdown of the potentiometric surface in Kaukauna was at least $22.9 \mathrm{~m}$ below predevelopment conditions by 1954, with as much as $10.6 \mathrm{~m}$ of this drawdown occurring between 1947 and 1954. This left few remaining flowing artesian wells in the region [15].

Knowles [13] provides a thorough description of the pumping changes and corresponding confined aquifer water level changes that occurred in central Brown County during the middle of the 20th century. In central Brown County, groundwater withdrawals from the confined sandstone aquifer averaged about 22.7 ML/day by 1940, 37.8 ML/day in 1950, and 49.2 ML/day in the first half of 1957.

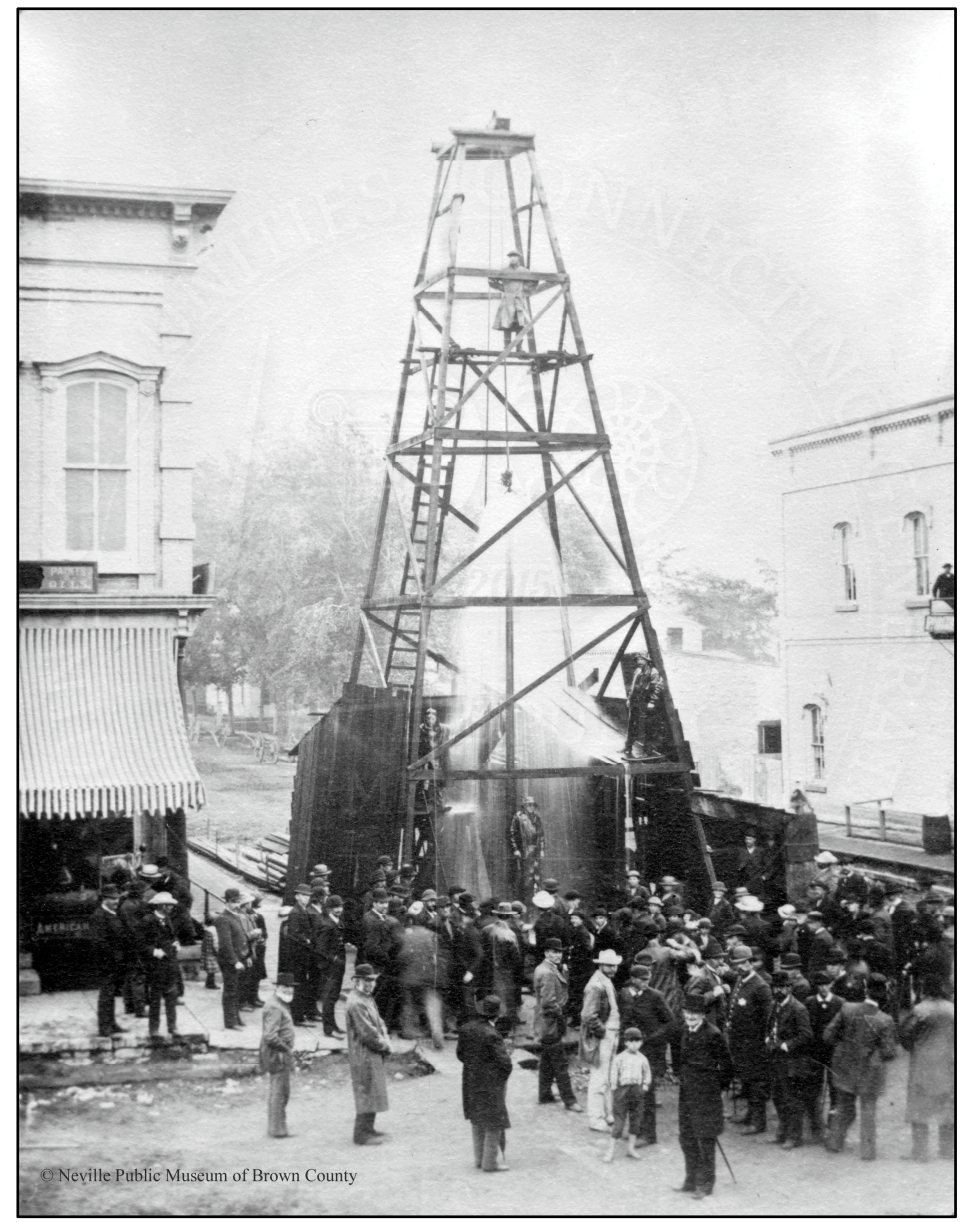

Figure 5. Photograph of flowing artesian conditions encountered during drilling of a well into the confined sandstone aquifer in De Pere, Wisconsin ca. 1890. Image courtesy of the Neville Public Museum in Green Bay. 

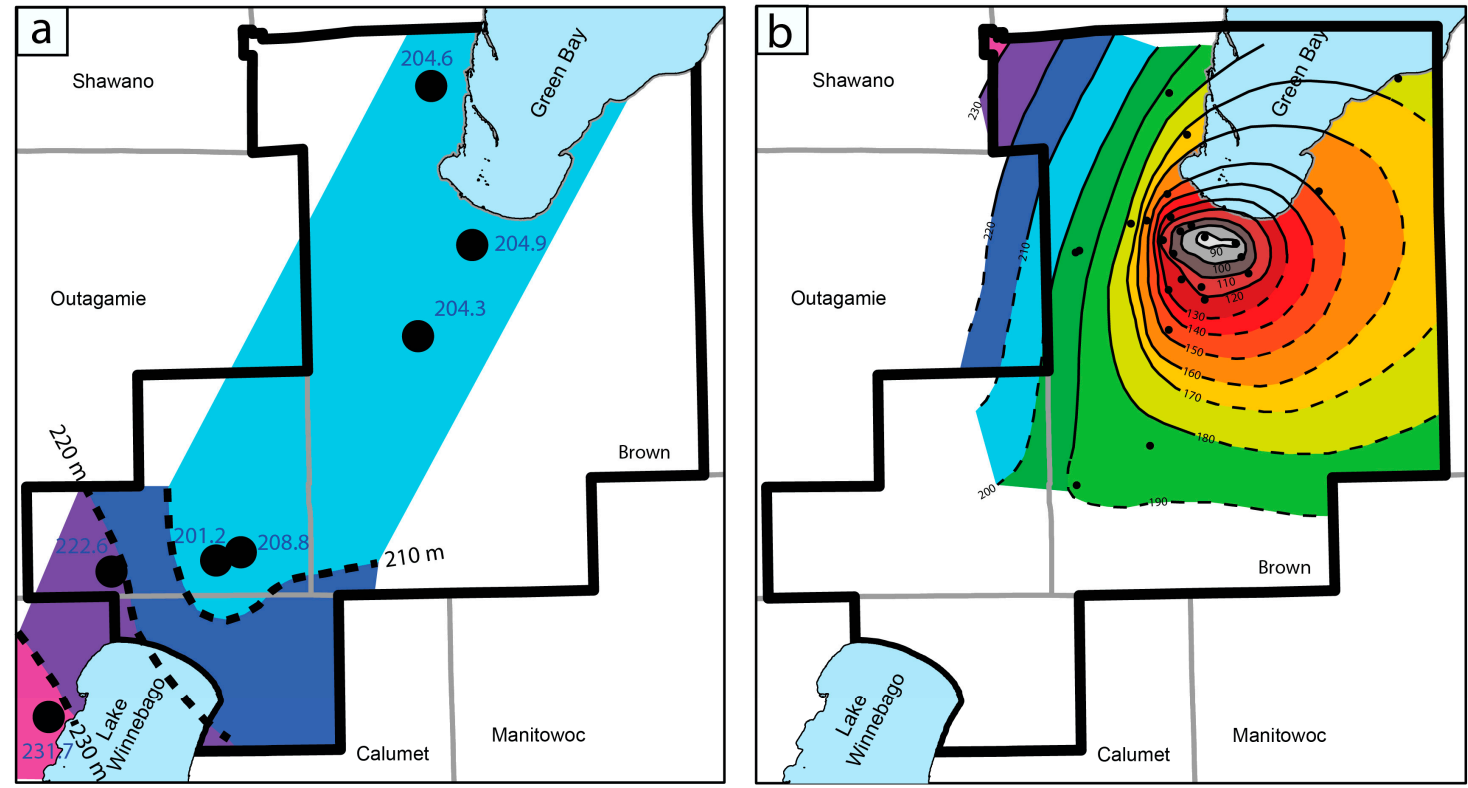

Predevelopment Conditions (1880-1900)
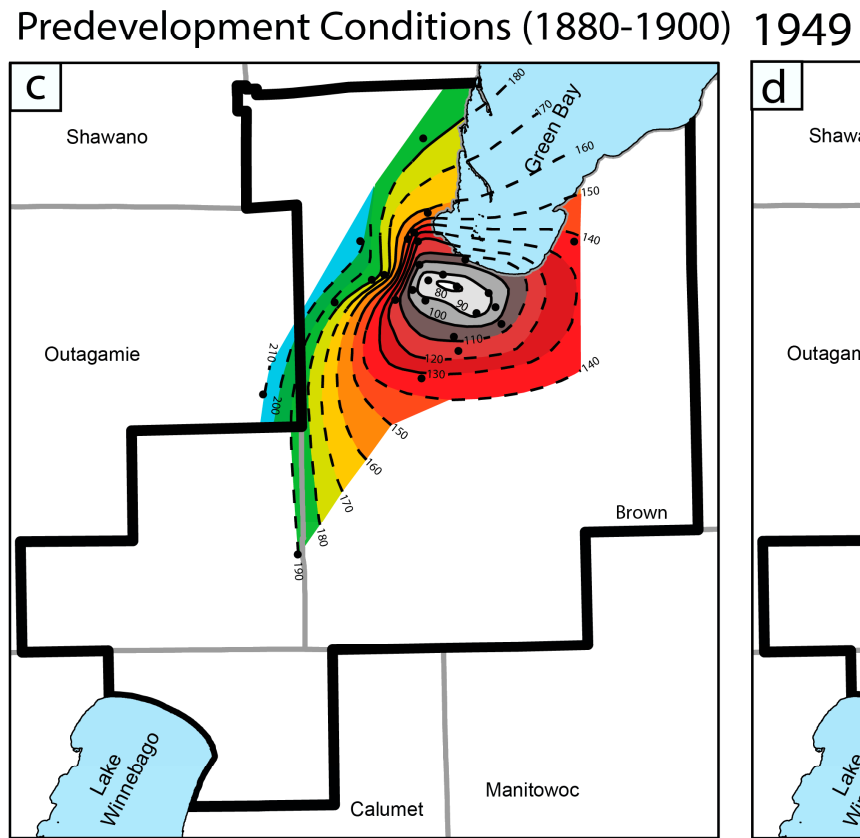

\section{Contour Interval $=10 \mathrm{~m}$}

\section{Potentiometric Levels}

\begin{tabular}{|c|c|c|c|c|c|}
\hline$\square<80 \mathrm{~m}$ & $100-110 \mathrm{~m}$ & $130-140 \mathrm{~m}$ & $\square 160-170 \mathrm{~m}$ & ] $190-200 \mathrm{~m}$ & 220-230 m \\
\hline $80-90 \mathrm{~m}$ & $110-120 \mathrm{~m}$ & $140-150 \mathrm{~m}$ & $\square 170-180 \mathrm{~m}$ & 200-210 m & $230-240 \mathrm{~m}$ \\
\hline$\square 90-100 \mathrm{~m}$ & $120-130 \mathrm{~m}$ & $150-160 \mathrm{~m}$ & 180-190 m & $210-220 \mathrm{~m}$ & \\
\hline
\end{tabular}

Figure 6. Regional maps of the potentiometric surface in the Cambrian-Ordovician confined sandstone aquifer from predevelopment conditions through the first transition from groundwater to surface water. For reference, the bay of Green Bay is $176.8 \mathrm{~m}$ above mean sea level. White color indicates areas with no data. (a) Water levels circa 1900 with the best known estimate of the predevelopment conditions in the aquifer using data from [12]; (b) The potentiometric surface during 1949 [14]; (c) The potentiometric surface during 1957 [13], immediately predating the first transition from groundwater to surface water by the City of Green Bay in 1957; (d) The potentiometric surface during 1960, three years after the first transition from groundwater to surface water by the City of Green Bay in 1957 [13]. 


\subsection{Transition \#1-1957-1960 Switch by City of Green Bay to Surface Water Pipeline}

Plans to make the first switch from groundwater to surface water supplies began in 1953 when a study by the Green Bay Water Commission warned that aquifer levels were falling in Brown County. Two years later in 1955, the Green Bay Water Commission voted to build a water pipeline to Lake Michigan at a cost of $\$ 5$ million, which was approved by the city council and the mayor. At this time, the nearby villages of De Pere and Allouez refused to join the regional water commission for political and economic reasons [46]. They likely reasoned that the reduced use by Green Bay would increase the amount of groundwater available for their communities. This decision was not without political consequence. After unsuccessful reelection, all members of the city council and the mayor of Green Bay were replaced. In 1955, the City of Green Bay was sued to stop construction of the pipeline. The Wisconsin State Supreme Court ruled in favor of the Green Bay Water Commission allowing for construction of the pipeline to begin [47].

Completion of the new $43 \mathrm{~km}$ pipeline between Green Bay and Lake Michigan (Figure 2) occurred in 1957. At this time, Green Bay stopped using most of its wells, allowing for major regional recovery of the northern cone of depression centered beneath central Brown County. Cessation of pumping by Green Bay during August 1957 resulted in an overall reduction in pumping from the confined aquifer from about 49 million liters per day to about 20.8 million liters per day after the switch to surface water. This resulted in rapid recovery of the potentiometric surface in central Brown County. Within just 3 years between 1957 and 1960, the potentiometric surface in the center of the northern cone rose from about $78 \mathrm{~m}$ above sea level to around $148 \mathrm{~m}$ above sea level, with a maximum recovery of up to $87.8 \mathrm{~m}$ on the west side of Green Bay [13] (Figure 6).

\subsection{Regional Growth (1960-2000)}

During the following decades, the population of the Green Bay metropolitan region increased, especially in De Pere, Allouez, and other communities surrounding Green Bay that still relied on groundwater from the deep sandstone aquifer. The focus of major pumping shifted southward to De Pere and Allouez in central Brown County. Figure 7 illustrates both the major recovery in 1957, as well as the subsequent water level fall due to regional growth from 1960 to about 2005.

In the mid to late 1970s, predictions were made warning of groundwater shortages within 10 to 20 years for central Brown County. Engineers predicted an additional drawdown of 8.2 to $9.1 \mathrm{~m} /$ year if the City of Green Bay began pumping 37.9 ML/day. They also recommended that regardless of whether Green Bay decided to utilize its wells again that metropolitan communities surrounding Green Bay should proceed as rapidly as possible to develop an alternative water supply source due to eventual water level declines that would render their wells inadequate [48]. By 1979, about $49 \mathrm{ML}$ per day were being pumped from Brown County [16]. This led to a 1980 lawsuit by the City of De Pere to prevent Green Bay from using its wells during the summer months, which constituted the seasonal demand peaks. Green Bay agreed to voluntarily shut down their wells for the specified time period [46].

Subsequent water use studies warned that groundwater levels in Brown County would continue to fall, with a corresponding rise in contaminants such as dissolved arsenic and radium. Figure 8a illustrates the potentiometric surface in the Northeast GMA during 1990. In 1992, The Brown County Planning Commission Potable Water Study Committee concluded that serious groundwater supply issues were imminent and groundwater could not supply the long-term needs of the Green Bay area communities. They recommended that a lake water source be pursued [49].

In a continuation of decades of political disagreement, the City of Green Bay mayoral race resulted in the first new mayor in 16 years. Campaign slogans such as "No Giveaway of Water System to Suburbs" indicated how important the issue was to the region [46].

Walker et al. [20] concluded that all of the water demand for the southern portion of the GMA through the year 2030 could be supplied by groundwater if communities in the central Brown County converted to surface water sources. This claim might not have been accurate for several reasons. First, 
Conlon's 1998 model underestimated drawdown by approximately $15 \mathrm{~m}$ in Brown County wells, possibly due to the limited information on structural faults, stratigraphic variations in the sandstone aquifer, and the thickness of unconsolidated Pleistocene glacial deposits that act as a confining layer. In addition, little was known about aquifer compartmentalization in the 1990s in the Northeast GMA, but subsequent research suggests that a major east-west dip-slip fault trends between the two cones of depression [22,24] and likely acts as a major hydrologic barrier for the confined sandstone aquifer [28,29].

A potentially important effect of drawdown is the geochemical reactions that can take place in the event that water levels are lowered to a position below the base of the confining layer (i.e., below the top of the aquifer). Northeastern Wisconsin has an extensive regional groundwater quality problem with arsenic and other metals related to oxidation of a sulfide cement horizon at the top of the Ancell Group (e.g., $[35,50,51])$. While this problem is most prevalent along the western border of the Northeast GMA, a concern is that dewatering of the top of the Ancell Group near the center of the northern cone of depression might oxidize sulfide minerals in the aquifer. Several wells in the northern cone were observed to have water levels below the top of the Ancell Group as early as 1950 [14], but the water quality implications of this event are not known. More recently, Maas [26] demonstrated that several wells in the northern cone again had water levels below the top of the confined sandstone aquifer in 2005, and in at least one case as recently as 2011. While ongoing research is evaluating this issue, it does not appear that significant problems related to oxidation have impacted municipal supply wells, but data are limited.

\section{Hydrographs for USGS Monitored Wells in Northern Cone}

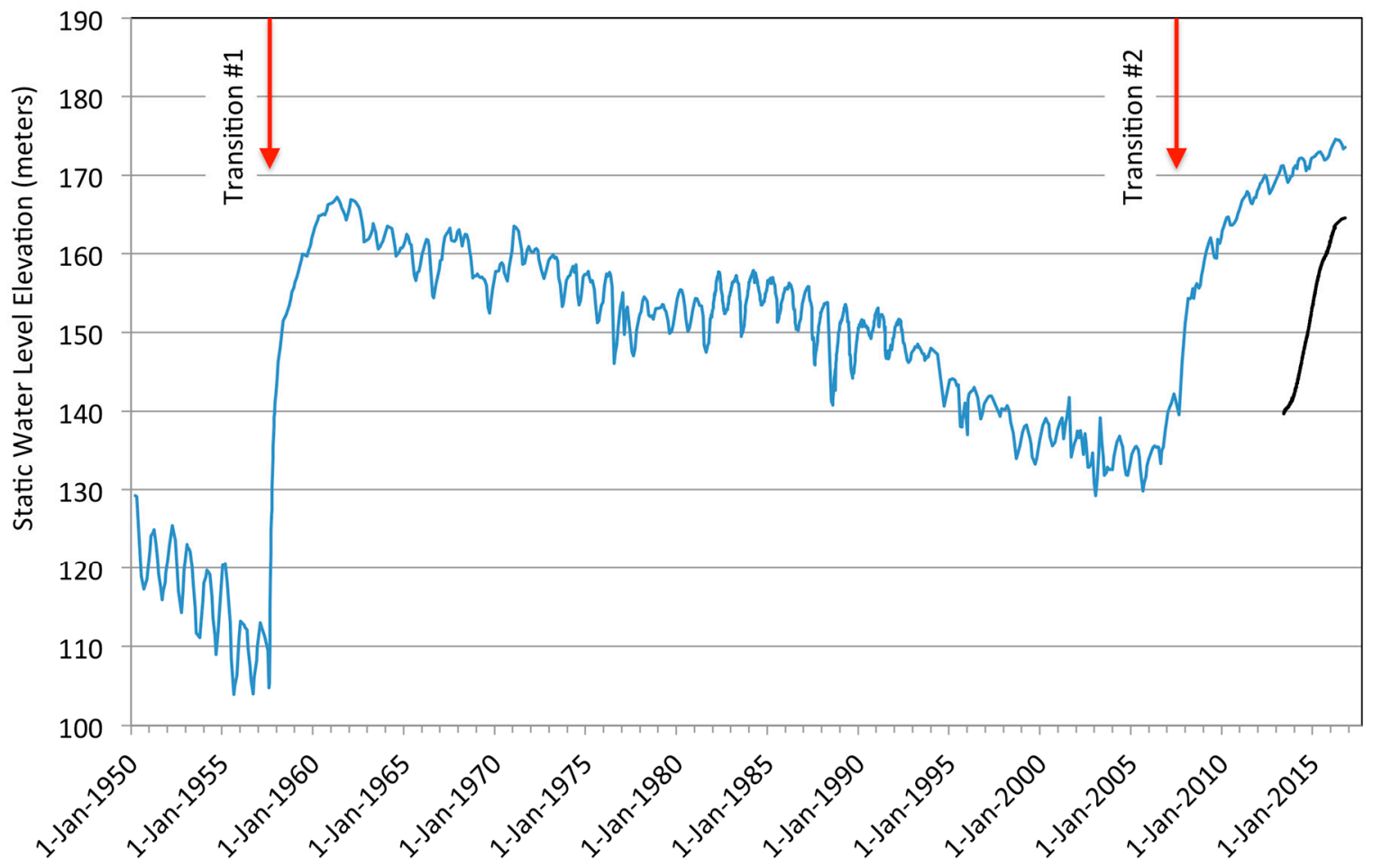

Figure 7. Long-term hydrographs of USGS monitoring wells in Green Bay region (central Brown County) from [41]. Red arrows indicate the two major transitions from groundwater to surface water supplies by Brown County municipalities in 1957 and 2007. Blue line is well BN-076, and Black line is well BN-0435. Note that the drawdown for BN-076 was not as significant at this location because it is on the northern edge of the cone of depression, and by 2005, the northern cone had moved southward to De Pere. BN-0435 is located near the center of the northern cone, but was not installed until after most of the recovery had already occurred. 

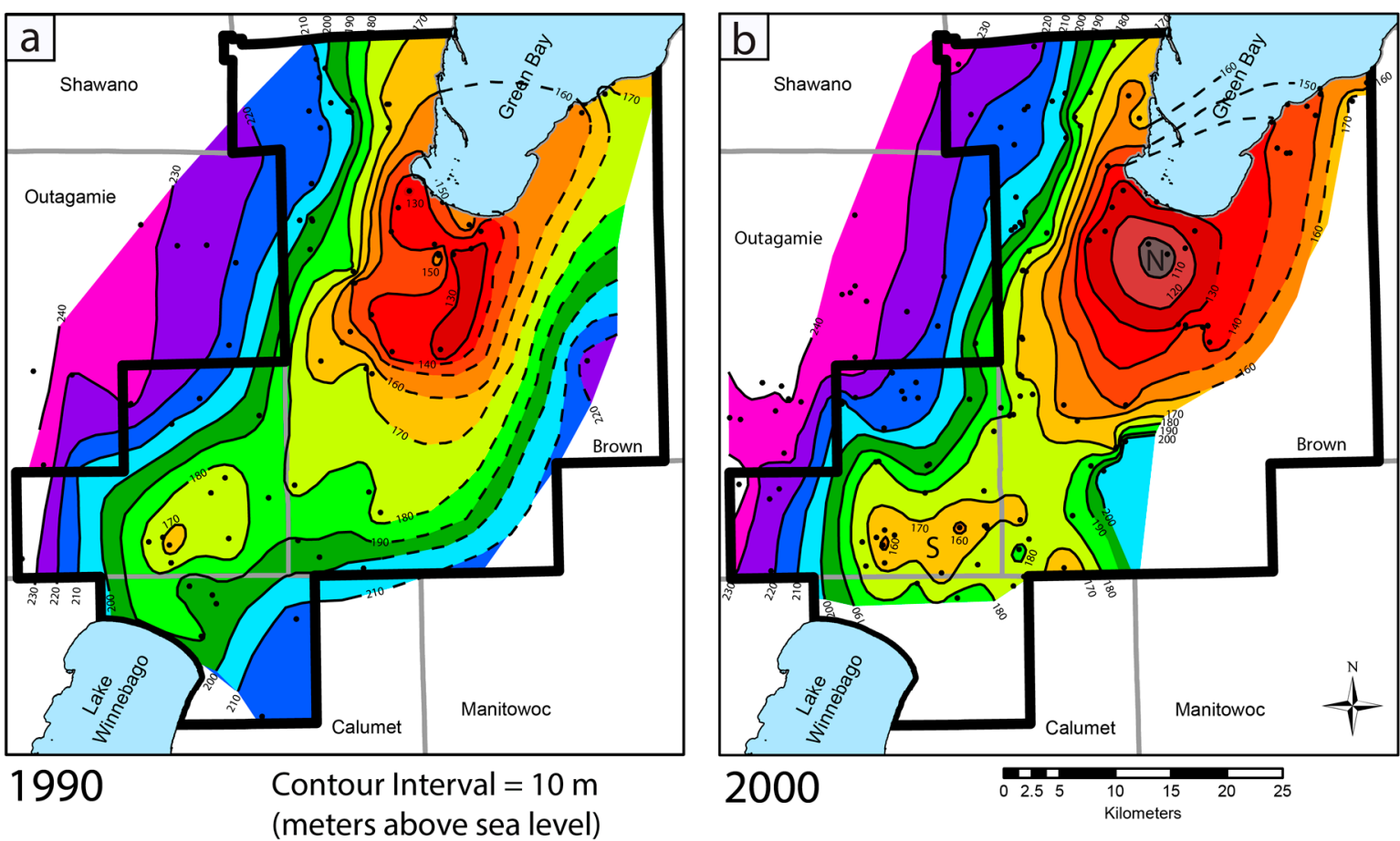

\section{Potentiometric Levels}

\begin{tabular}{|c|c|}
\hline$<80 \mathrm{~m}$ & $100-110 \mathrm{~m}$ \\
\hline $80-90 \mathrm{~m}$ & $110-120 \mathrm{~m}$ \\
\hline $90-100 \mathrm{~m}$ & $120-130 \mathrm{~m}$ \\
\hline
\end{tabular}
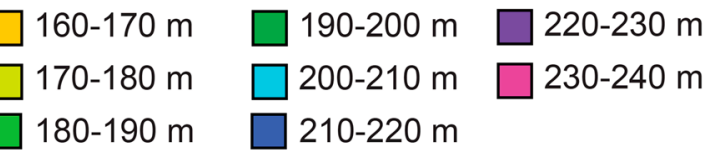

Figure 8. Maps of the potentiometric surface in the Cambrian-Ordovician confined sandstone aquifer during (a) 1990 and (b) 2000. "S" indicates the location of the southern cone of depression near the Fox Cities region. " $\mathrm{N}$ " indicates the location of the northern cone of depression in central Brown County near Green Bay and De Pere. Well locations are from Maas [26].

\section{Recent History of the Northeastern Wisconsin Groundwater Management Area (1998-Present)}

\subsection{Formation of the Central Brown County Water Authority}

A consortium of 12 Brown County municipalities formed in 1998 and was followed by negotiations between Green Bay and other municipalities in 1999. In 1998, the Central Brown County Water Commission introduced state legislation that allowed for the formation of joint water authorities in Wisconsin. In 1999, the Central Brown County Water Authority (CBCWA) was formally established under the new state law. In the same year, the City of Manitowoc, located approximately $56 \mathrm{~km}$ to the southeast of Green Bay along Lake Michigan (Figure 2), built a new microfiltration water treatment facility with substantial additional capacity.

\subsection{Radium Regulations as the Driver for a Second Transition}

A major turning point leading to the second major groundwater to surface water transition in the Northeast GMA occurred during 1998. The United States Environmental Protection Agency (USEPA) set December 2006 as the deadline requiring all municipalities to meet federal drinking water standards for dissolved radium. The standard limited combined radium $\left({ }^{226} \mathrm{Ra}\right.$ and $\left.{ }^{228} \mathrm{Ra}\right)$ to a threshold of $5 \mathrm{pCi} / \mathrm{L}(0.185 \mathrm{~Bq} / \mathrm{L})$, and fines of $\$ 5000$ per day were to be levied for municipalities that exceeded this value. The Northeast GMA is located within a region of high dissolved radium levels, and most municipal wells in central Brown County would exceed the new USEPA standard for dissolved radium. By the year 2000, water levels continued to decline (Figures 7 and 8b). 
Between 2000 and 2002, disagreements over whether Green Bay or the Central Brown County Water Authority would maintain control of the pipelines was seen as a major impediment to cooperation. The City of Green Bay did not give up pipeline control without prorated costs of the existing pipeline since construction in the 1950s being paid by the suburbs. Several CBCWA members refused any compensation to Green Bay because they wanted all rates to be the same. Along with election of a new Green Bay mayor in 2003, and subsequent changes to water commissioners and other personnel, it was clear that no deal was possible and that certain suburbs refused to buy water from Green Bay. As a result, Green Bay became a "defunct" member of the CBCWA. Additional political events resulted in the breakup of the original 12-member CBCWA [46,52]. In 2004, the village of Ashwaubenon and the Town of Scott agreed to a separate deal to buy water from the Green Bay Water Utility. Three other municipalities left the CBCWA and opted to keep their confined aquifer wells in operation.

In 2004, the CBCWA finalized an agreement with the City of Manitowoc to obtain water from their new treatment plant, which resulted in the decision to build another $105 \mathrm{~km}$ (65 mile) long pipeline at an estimated cost of \$106 million USD. By 2005, the CBCWA members consisted of Allouez, Bellevue, De Pere, Howard, Lawrence, and Ledgeview. The total pipeline cost, including recently added storage facilities is more than $\$ 130$ million [53]. In 2006, the Green Bay Water Utility built a second pipeline parallel to its existing pipeline at an estimated $\$ 35$ million, which resulted in additional capacity for Scott, Ashwaubenon, and others in the future.

During this same period, Wisconsin Act 310 directed the WDNR to establish two GMAs for portions of the state in which the potentiometric surface has been reduced by at least 150 feet $(45.7 \mathrm{~m})$ (see Section 1.2). The timing of this legislation was beneficial to our understanding of the second major transition from groundwater to surface water in the Northeast GMA.

\subsection{Transition \#2-2005 to Present Switch by Several Communities in Central Brown County}

By 2005, the two well-developed cones of depression are at their maximum drawdown values (Figure 9a). The "northern cone" is represented by communities in central Brown County and is centered near De Pere and Allouez, just south of Green Bay. Water level elevations in wells open to the confined sandstone aquifer were similar to those in early 1957 before the first transition to surface water by Green Bay. At this time, the maximum total drawdown from predevelopment conditions occurred, with approximately $128.6 \mathrm{~m}$ of total drawdown near the center of the northern cone. The "southern cone", which was located in southeastern Outagamie County and centered over the Fox Cities region of Kaukauna, Kimberly, and Little Chute also experienced significant drawdown.

The main transition from groundwater to surface water by 8 communities took place during 2006 and 2007. The village of Ashwaubenon and the Town of Scott switched in 2006 by connecting to the Green Bay Water Utility system. The remaining six communities constituting the CBCWA switched by late summer 2007, after construction problems delayed completion by the end of 2006 USEPA deadline. Since that time, two other communities have followed. In 2011, the village of Hobart began using surface water from Green Bay Water Utility's pipeline, and the village of Wrightstown recently joined an extension of the same pipeline in Fall 2016.

Although some wells in these eight communities were permanently abandoned, most of these wells remain functional and have been placed on emergency backup status, similar to the municipal wells in Green Bay. In the event that pipeline problems or other reasons require the regions backup wells to return to service, these wells have a reduced frequency of water quality testing. Nitrate and bacteria, however, are sampled either monthly or quarterly, depending on the municipality.

Figures 10-12 present the pumping history for parts of the Northeast GMA between 2006 and 2014. A clear change in pumping rates for municipalities in the northern cone occurred between 2006 and 2008 (Figure 10). A clear seasonal signal is present due to higher demand during summer months, in part due to irrigation wells for golf courses, swimming pools, etc. No substantial changes 
in pumping occurred in the southern cone (Figure 11) during this period. Total pumping for the entire Northeast GMA, including outlying areas, is shown in Figure 12.

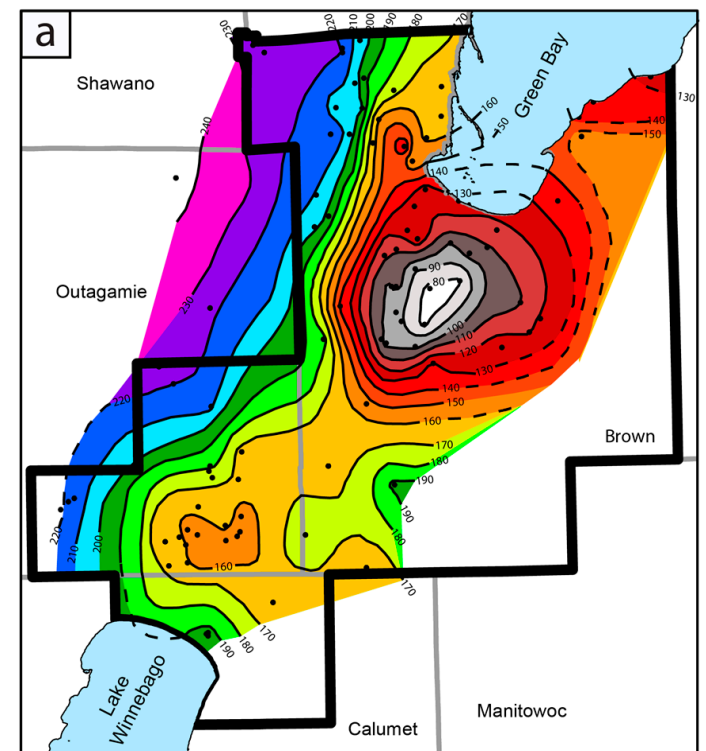

2004-2005

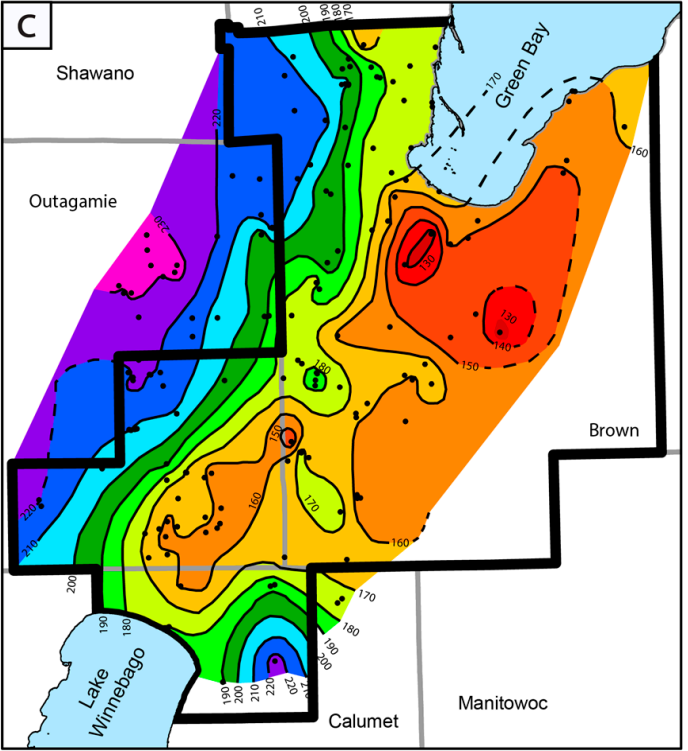

2011-2012

(meters above sea level)

Potentiometric Levels

\begin{tabular}{|c|c|c|}
\hline$\square<80 \mathrm{~m}$ & $\square 100-110 \mathrm{~m}$ & ] $130-140 \mathrm{~m}$ \\
\hline$\square$ 80-90 m & ]110-120 m & $140-150 \mathrm{~m}$ \\
\hline$\square 90-100 \mathrm{~m}$ & $120-130 \mathrm{~m}$ & $150-160 \mathrm{~m}$ \\
\hline
\end{tabular}

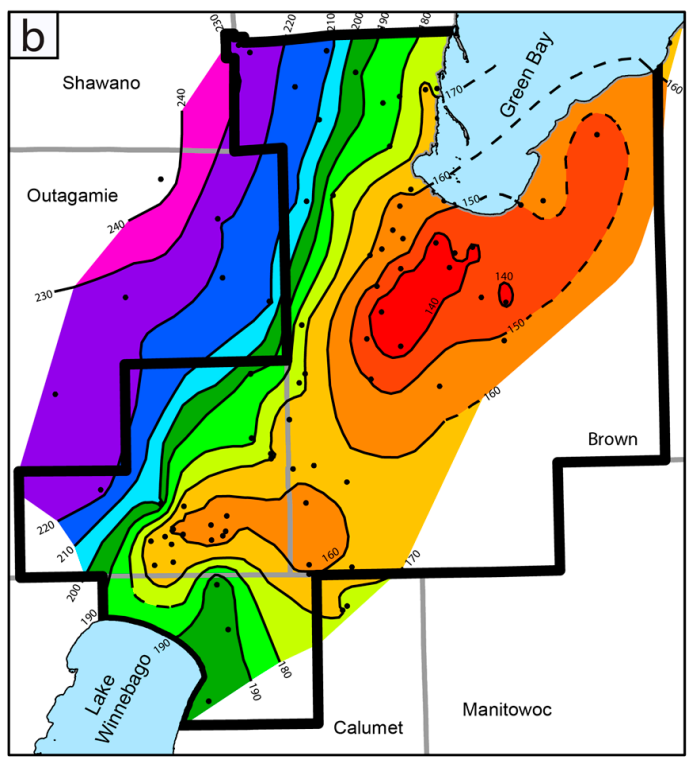

2008
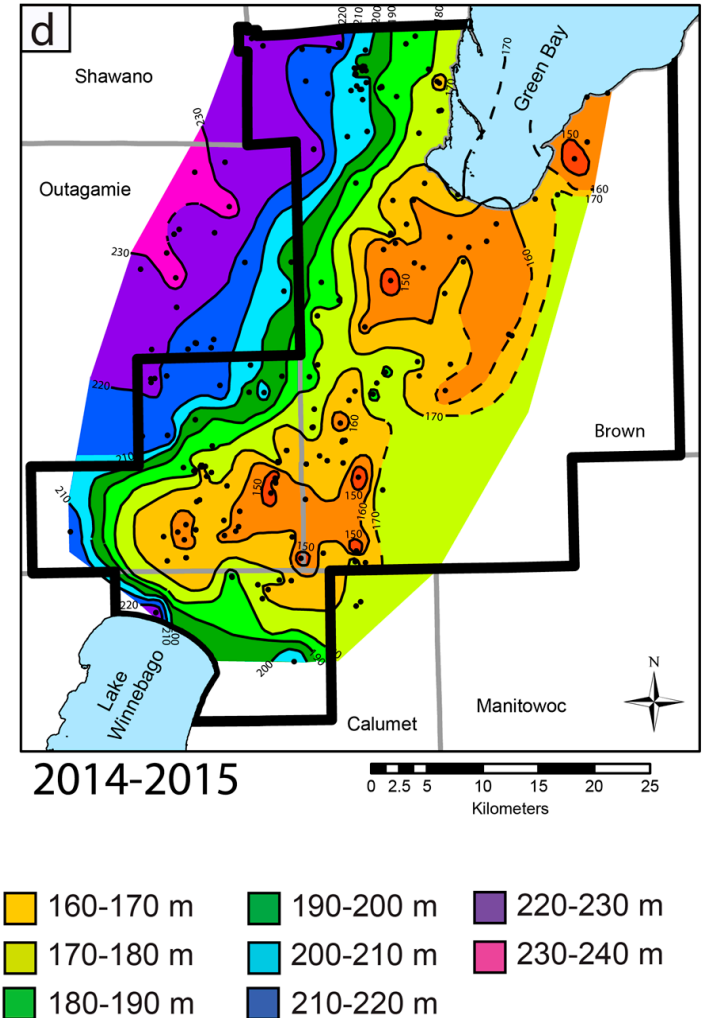

$190-200 \mathrm{~m}$

200-210 m

$210-220 \mathrm{~m}$

Figure 9. Maps of the potentiometric surface in the Cambrian-Ordovician confined sandstone aquifer illustrating the second major transition from groundwater to surface water in central Brown County. (a) Water levels during 2005 and immediately before the second transition by eight surrounding communities. Compare 9a to Figure $6 c$ to see how the position of the northern cone shifted southward about $6 \mathrm{~km}$ due to water use changes in the northern cone; (b) Water levels during 2008, just after the transition, illustrating the major recovery that had occurred in the northern cone; (c,d) further recovery of the northern cone occurs by 2011-2012 and 2014-2015, respectively, while continued drawdown occurs in the southern cone. 
Monthly Withdrawals from the Confined Aquifer in the Northern Cone (Central Brown County) January 2006 - December 2014

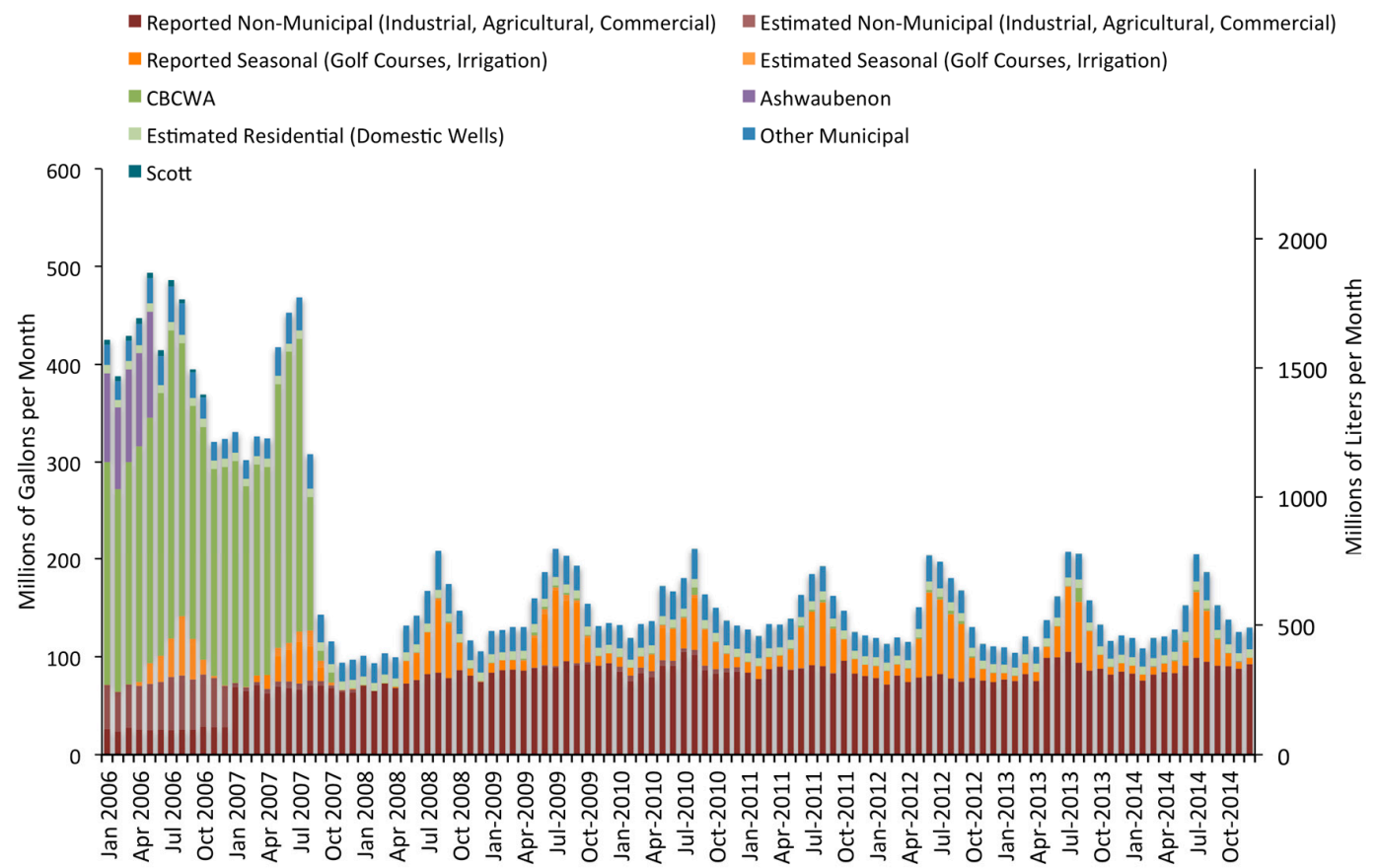

Figure 10. Monthly groundwater withdrawals from central Brown County (Northern Cone) between 2006 and 2014.

\section{Monthly Withdrawals from the Confined Aquifer in the Southern Cone (Fox Cities) January 2006 - December 2014}

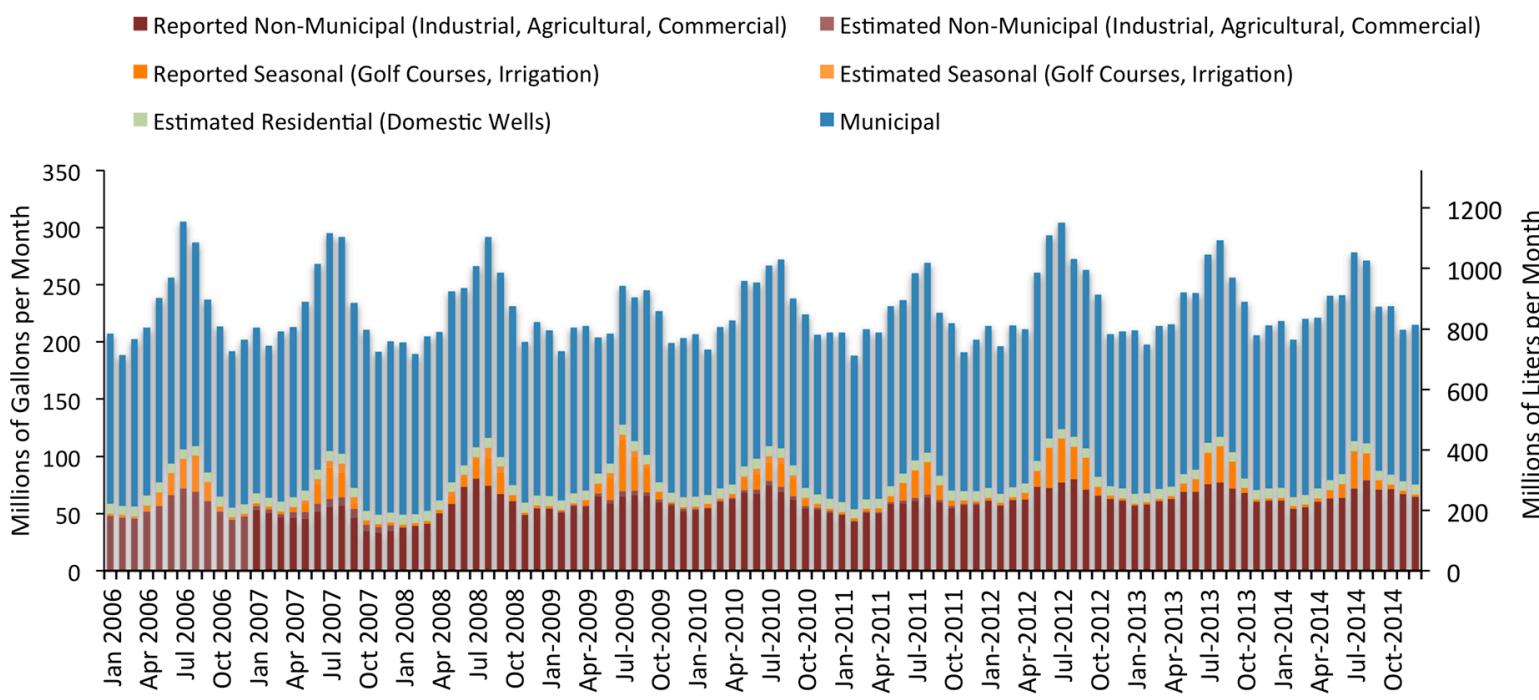

Figure 11. Monthly groundwater withdrawals from the Fox Cities region (Southern Cone) between 2006 and 2014.

A significant change in the type of water use occurred during Transition \#2. Before the switch, total pumping in central Brown County was about 62.23 ML/day (Table 2), with municipal pumping comprising about $80 \%$ of total groundwater use. After the switch, total pumping in central Brown County decreased to about $15.86 \mathrm{ML} /$ day (Table 3), with industrial pumping now comprising the majority of groundwater use. 


\section{Monthly Withdrawals from the Confined Aquifer Entire Northeast GMA Region January 2006-December 2014}

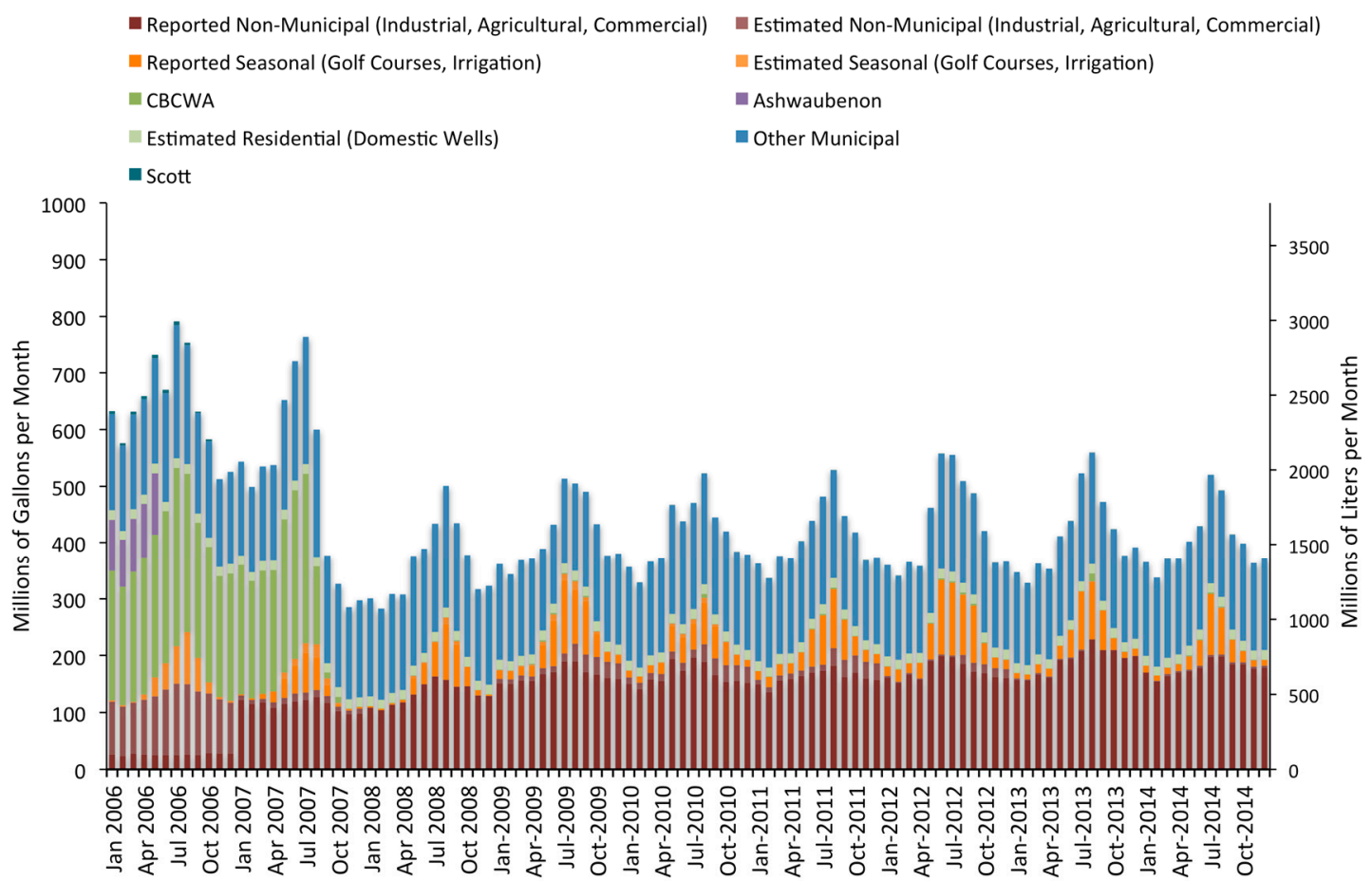

Figure 12. Monthly groundwater withdrawals from the entire Northeast Groundwater Management area between 2006 and 2014.

Table 2. Water use categories for water withdrawn from the confined sandstone aquifer in Central Brown County before eight communities switched from groundwater to surface water during 2006-2007. Data are calculated from [26].

\begin{tabular}{cccc}
\hline Category & Volume (ML/day) & $\begin{array}{c}\text { Percent of Total } \\
\text { (October-March) }\end{array}$ & $\begin{array}{c}\text { Percent of Total } \\
\text { (April-September) }\end{array}$ \\
\hline Municipal & 49.6 & 83.0 & 77.1 \\
Industrial & 9.1 & 15.2 & 14.1 \\
Seasonal (Irrigation) & $0.0-4.5$ & $<1$ & 7.1 \\
Residential & $\underline{1.06}$ & $\underline{1.8}$ & $\underline{1.7}$ \\
Total: & $\mathbf{5 9 . 7 3 - 6 4 . 2 8 ( \text { ave. 62.23) }}{ }^{\mathbf{1 0}}$ & $\mathbf{1 0 0}$ & $\mathbf{1 0 0}$ \\
\hline
\end{tabular}

${ }^{1}$ Seasonal water use is mainly April through September; ${ }^{2}$ Weighted average.

Table 3. Water use categories for water withdrawn from the confined sandstone aquifer in Central Brown County after eight communities switched from groundwater to surface water during 2006-2007. Data are calculated from [26].

\begin{tabular}{|c|c|c|c|}
\hline Category & Volume (ML/day) & $\begin{array}{l}\text { Percent of Total } \\
\text { (October-March) }\end{array}$ & $\begin{array}{c}\text { Percent of Total } \\
\text { (April-September) }\end{array}$ \\
\hline Municipal & 3.14 & 23.6 & 17.6 \\
\hline Industrial & 9.1 & 68.4 & 51.0 \\
\hline Seasonal (Irrigation) ${ }^{1}$ & $0.0-4.5$ & $<1$ & 25.5 \\
\hline Residential & $\underline{1.06}$ & $\underline{8.0}$ & 5.9 \\
\hline Total: & $13.29-17.83$ (ave. 15.86$)^{2}$ & $\overline{100}$ & 100 \\
\hline
\end{tabular}

${ }^{1}$ Seasonal water use is mainly April through September; ${ }^{2}$ Weighted average. 
Transition \#2 is well illustrated during this period by hydrographs from various central Brown County wells in the confined sandstone aquifer. Figure 7 (above), Figure 13a, and Supplementary File S2 present selected wells from central Brown County that show rapid recovery of the potentiometric surface between 2005 and 2008, followed by continued rising water levels to the present day in some areas. Total recovery has been at least 45.7 to $58 \mathrm{~m}$ in the northern cone since the transition, based upon water level records supplied by the Green Bay Water Utility. For example, in northern Green Bay (Figure 7), water levels are at their highest levels since at least 1950. More distally located wells, such as the village of Pulaski northwest of Green Bay, showed no major changes, despite their presence in the Northeast GMA (see Supplementary File S2).

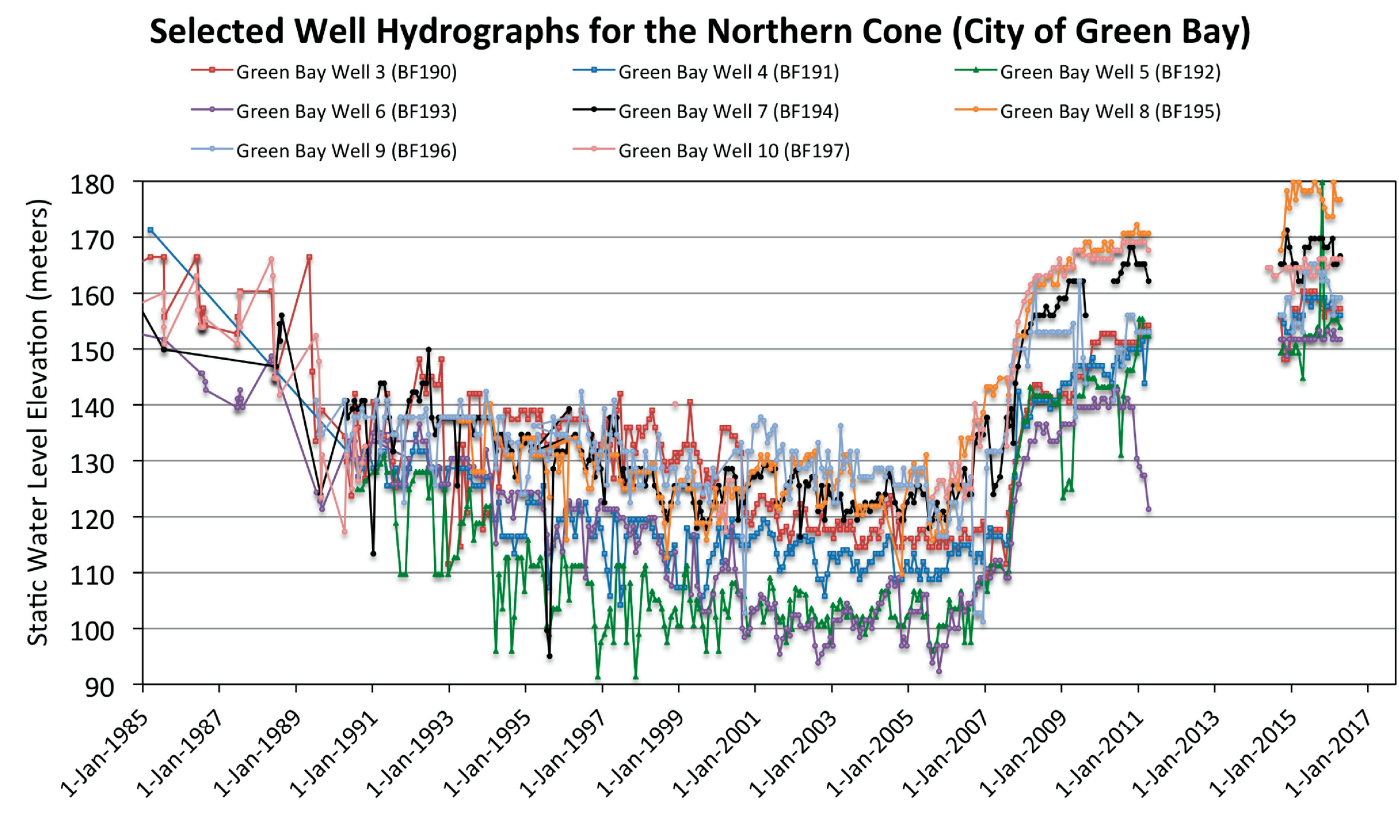

Selected Well Hydrographs for the Southern Cone (Kimberly)

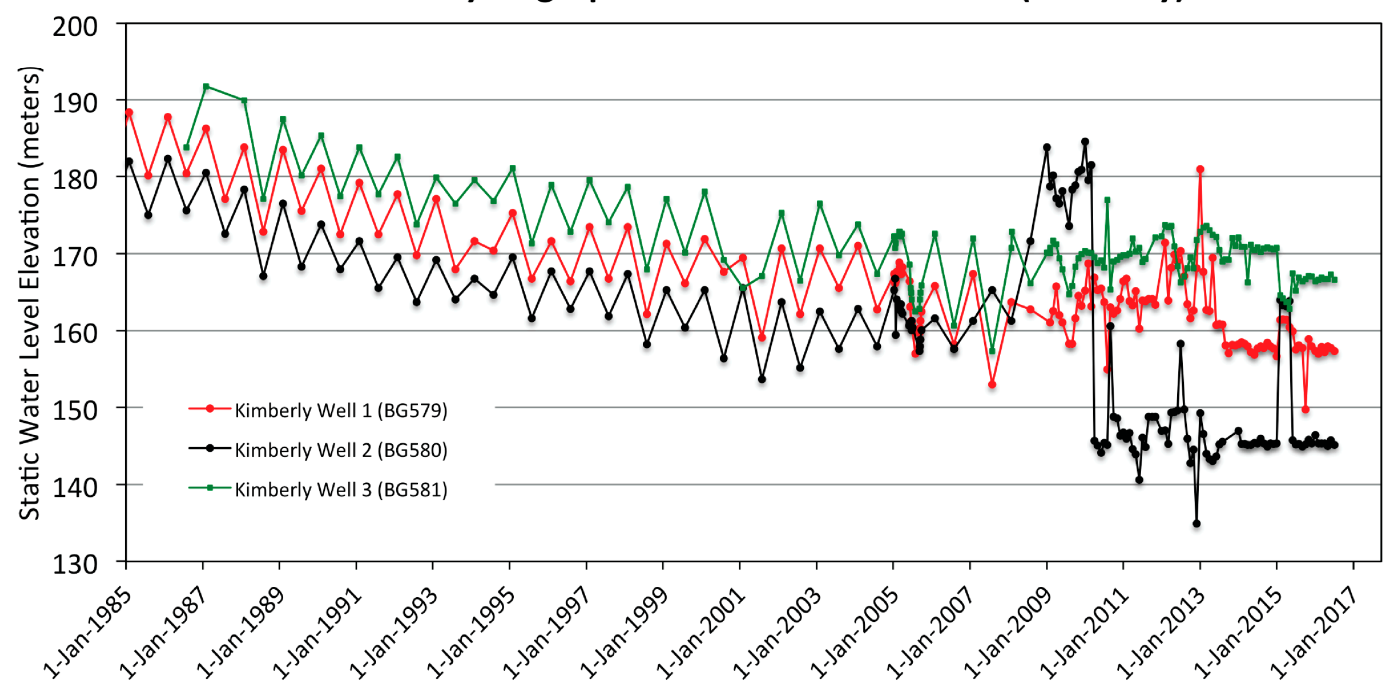

Figure 13. Hydrographs of selected municipal wells in the Northeast GMA over the past 30 years. (a) Hydrographs for the northern cone show a steady decline until 2006-2007 when the second transition from groundwater to surface water occurred and water levels rebounded dramatically. Data from April 2011 through mid-2014 were missing from the Green Bay Water Utility (GBWU) records; (b) Hydrographs for the southern cone show a long steady drop in water levels over time. The anomaly in Well 2 does not appear to be related to the transition from groundwater to surface water in the northern cone. 
More recovery has occurred near the center of the cone, with lesser recovery near the margins, but the full magnitude of recovery is difficult to determine because wells closer to the center of the cone (De Pere and Allouez) are no longer capable of yielding water level measurements. However, observation well BN-0435 (Figure 7), situated near the center of the northern cone, has shown $35 \mathrm{~m}$ of recovery since installation in mid-2010, presumably after most of the potentiometric surface recovery had already occurred between 2006 to early 2010. Based on data from nearby wells in 2004-2005, as much as 67 to $88 \mathrm{~m}$ of recovery might have taken place at this location near the center of the northern cone between 2005 and 2016.

The southern cone shows a steady downward trend in water levels (Figure 13b) in the absence of significant changes in pumping rates (Figure 11). Reduction of pumping near the northern cone has apparently not significantly affected the southern cone. This may be due to several factors. First, the two cones are about $34 \mathrm{~km}$ apart. In addition, a major east-west fault is known to compartmentalize the aquifer and may act as a barrier to regional groundwater flow. Evidence for this includes changes in major ion composition and stable isotopic composition of hydrogen and oxygen on either side of the fault zone [28,29]. Additionally, pumping changes resulting from the 2016 switch to surface water by the village of Wrightstown, located between the two cones, are not captured by water level data available during this study.

Several contour maps of the potentiometric surface in the Cambrian-Ordovician confined sandstone aquifer illustrate the changes during the second transition period between 2005 and the present. Figure 9 shows a deep cone of depression centered near central Brown County that shallows between 2005 and 2015. By 2016, water levels in many central Brown County wells appear to have stabilized, but some areas continue to show increasing water levels (e.g., Figures 7 and 13a), albeit with a seasonal component due to differences in seasonal pumping rates.

While total drawdown from predevelopment conditions is more difficult to estimate for the southern cone, drawdown of at least $56.4 \mathrm{~m}$ has occurred in Kaukauna and Little Chute, and perhaps as much as $64 \mathrm{~m}$ in Kimberly. During mid-2016, SWLs in Little Chute well \#3 indicated cumulative drawdown of about $78 \mathrm{~m}$, although this might be temporary due to well maintenance scheduling.

\section{Discussion and Implications}

Globally, many areas suffer from declining groundwater levels and accelerating rates of depletion [1,54], and few aquifers have shown large-scale water level recovery due to improved management changes or alternative water supplies (e.g, $[3,4,54]$ this study). In many cases, groundwater quality and quantity degradation occur due to increasing salinity, ground subsidence, and reduction in surface streamflow (e.g., [54]). However, the study area in northeastern Wisconsin does not suffer from these common effects because the principal aquifer is hosted by Paleozoic sandstone under confined conditions. In contrast, flowing artesian wells, flooding of quarries, and water quality changes relating to oxidation of sulfides appear to be of most concern.

\subsection{Unintended Consequences}

The recent transition from groundwater to surface water by 10 communities in Brown County might lead to specific unintended consequences including flowing wells, flooding of quarries, and possible spring activity. Many wells that are open to the confined sandstone aquifer have begun to flow since the transition to surface water in 2006 to 2007. These are most common to the northwest of Green Bay in the villages of Howard and Suamico. Well \#3 in the village of Howard (Figure 2) began flowing in 2009 [26], and many residential and commercial wells open to the sandstone aquifer also flow seasonally or continuously in this area. This has led to concern that inactive, improperly abandoned wells might begin to exhibit flowing artesian conditions. Some of these wells may still exist and are typically located in the basements of buildings in the urban areas of Green Bay, or near former railroad fill stations, despite the long established requirement by WDNR to permanently abandon (fill and seal) these wells. 
Another unintended consequence was accelerated flooding of a deep quarry resulting in flowing conditions. Also in the village of Howard, the Duck Creek Quarry penetrates the entire thickness of the Sinnipee Confining layer down to the top of the Ancell Group/St. Peter Sandstone. The quarry began filling in 2001 after the quarry ceased operation and dewatering pumps were turned off. At this time, the potentiometric surface was at or below the base of the quarry, and the flow of water was likely downward, recharging the sandstone aquifer below. Through compilation of historical photographs and direct measurements, Luczaj [55] demonstrated a change in the filling rate of the quarry that corresponded to pumping changes in the confined sandstone aquifer. Before the villages of Ashwaubenon and Howard ceased pumping groundwater in 2006 and 2007, respectively, the rate of water level rise was approximately $6.2 \mathrm{~cm}$ /week between 2002 and 2006. After the transition, the rate of rise of water levels in the quarry increased by $68 \%$ to $10.4 \mathrm{~cm} /$ week between 2007 and 2011. The quarry is only about $2.1 \mathrm{~km}$ south of the flowing municipal well in the village of Howard. By mid-2011, water levels reached the top of the bedrock, leading to lateral flow in unconsolidated Pleistocene sediments. This led the village of Howard to install an outfall to a nearby creek to avoid future problems. During May 2013, the quarry outfall had steady flow at approximately $530 \mathrm{~kL} /$ day.

Additional concerns of quarry flooding and even quarry floor buckling have been expressed by engineers regarding operating deep dolostone quarries near De Pere that approach the top of the Ancell Group [56].

Other possibilities include renewed flowing of springs and seeps in areas where fractures and other conduits allow for preferential vertical flow across the Sinnipee Group confining layer. The potential importance of such springs is now well known, but several clues suggest that preferential flow paths across the confining layer might exist. For example, recent engineering work in Green Bay has documented vertical fissures at least several meters long that cut through the Sinnipee Group dolostone [57]. While the Sinnipee Group does not have documented karst solution cavities within Brown County, other solution cavities in the same unit have been interpreted as hydrothermal solution cavities along northwest-trending structures near Chicago, Illinois [58].

Perhaps related, an enigmatic sinkhole in the Pleistocene glacial sediments occurs above one of the mapped northwest-trending faults along the East River in Allouez [22,59,60]. The origin of this sinkhole is not understood, but a connection with the confined sandstone aquifer is possible. At least one map from the late 1800s [61], when flowing artesian conditions would have been present, shows the feature to be a spring.

\subsection{Current State of the Aquifer and Apparent Trends}

As of 2016, water levels in the northern cone in central Brown County appear to have stabilized in many wells in the Green Bay region (Figures 9 and 13a), but some show slow, continued water level recovery (Figure 7). As described earlier, limited data are available near the center of the cone, but observation wells in Green Bay and Ashwaubenon show steady or slightly increasing water levels over time. Water levels in well BN-0435 have risen at a rate of about $6 \mathrm{~m}$ /year since installation in late 2010. Static water levels in Green Bay remain between about 16-27 m below ground level. Along the north side of Green Bay and north into Howard and Suamico, water levels continue to rise and are generally 3-5.5 m below ground level, and one of the wells in Howard has flowed since 2009. Water levels in BN-076 along the northern margin of the cone have risen steadily by about $1.5 \mathrm{~m} /$ year since 2010. In Wrightstown, located to the south between the two major cones of depression, water levels are rising at about $0.7 \mathrm{~m} /$ year during the past several years. Unfortunately, fewer data are available to monitor the water levels in the confined aquifer in recent years because of malfunctioning air lines, inaccessible well design, or well abandonment.

In the southern cone near the Fox Cities, water levels in most wells are steady, especially in Kaukauna, Darboy, Holland, and Forest Junction (File S2), with those wells showing the same water levels as those observed before the CBCWA transition in 2006 to 2007. However, two municipalities in the southern cone did show decreasing water level elevations. Wells in Kimberly showed overall 
falling water levels, with some complex patterns due to well pumping variations, but with water levels certainly below those observed in 2005 (Figure 13b). This pattern continues a long downward trend that began during the late 1980s, with a long-term decrease in water levels of approximately 26 to $24 \mathrm{~m}$ over the past 30 years. Wells in Little Chute were fairly steady until a few years ago when pumping schedules for the wells were changed due to maintenance activities [62], forcing well \#3 to be more heavily pumped. As a result, a rapid decline in the water level elevation has occurred, resulting in an additional $30 \mathrm{~m}$ of drawdown over the past 2.5 years (See File S2).

While flowing artesian wells open to the confined sandstone aquifer appear limited to the northwest of Green Bay in the villages of Howard and Suamico, it is possible that with further recovery, additional wells may begin flowing, even without further reductions in municipal or industrial well pumping rates.

\subsection{Effects of Future Pumping Changes}

Present groundwater abstraction from the confined sandstone aquifer in central Brown County is approximately 15.9 ML/day and is mainly comprised of industrial, and seasonal water uses. While golf course irrigation and other wells are unlikely to change significantly, potential ramifications of water use reductions by one or more major industries should be considered in future modeling efforts in the Northeast GMA. Significant reductions could lead to continued water level recovery in the aquifer approaching the predevelopment heads of around $29 \mathrm{~m}$ above land surface, resulting in flowing artesian well conditions similar to those seen in the early 1900s.

The recent switch by the village of Wrightstown to the Green Bay Water Utility (GBWU) surface water pipeline is unlikely to contribute much to the water level recovery in the region because of its small population ( $<3000$ people).

\subsection{Concerns over Arsenic and Sulfide Mineralization}

In some regions of the world, groundwater fluctuations and water level rebound can result in major water quality changes, such as acidification and release of heavy metals. In parts of England, rising water levels threaten underground railway systems and the stability of building foundations. This is exacerbated by concerns of $\mathrm{pH}$-reduced water relating to oxidation of sulfide mineralization in parts of the aquifer [54].

In Wisconsin, a significant concern regarding water quality in wells open to the confined sandstone aquifer stems from the fact that dewatering of the sandstone can occur in areas with greatest drawdown. Several wells in the central Brown County portion of the Northeast GMA reported static water level elevations below the top of the confined aquifer (File S3). While some wells are cased across the Ancell Group (Table 1), liberation of arsenic, nickel, cobalt, and other metals has been shown to be a problem in the aquifer when oxidative conditions prevail $[50,51,63,64]$. In the northern cone, at least five municipal or observation wells reported water levels that were below the top of the aquifer. One of these wells near the center of the cone (BN-0435) had a water level that did not reach the top of the aquifer until 2011, about four to five years after transition \#2 began in central Brown County. While initial analysis of emergency backup wells does not indicate significant water quality problems [65], water quality data are limited mainly to wells that are only open to the Cambrian portion of the aquifer, potentially limiting or delaying any response in water quality resulting from oxidation of the Ancell Group.

In the southern cone, at least four wells have or once had water levels below the top of the confined sandstone aquifer in the villages of Little Chute and Kimberly. A water quality analysis for this portion of the aquifer is planned for the future, but there has been concern voiced over the potential for increased arsenic and radium concentrations as water levels decline.

\subsection{Aquifer Sustainability}

The sustainability of groundwater quantity in the Northeast GMA varies somewhat between the two cones of depression. After transition \#2 in 2006 to 2007, the northern cone changed suddenly from 
conditions of rapidly declining water levels in 2005 to a sustainable condition as of 2016. While it is possible that future suburban growth outside the regions supplied by municipal water might once again increase demand as it did between 1957 and 2007, there is significant additional groundwater capacity available in central Brown County at the present time for population growth or industrial use.

The assessment of groundwater quantity is less clear in the southern cone, and so water levels must be monitored. While many wells exhibit stable water level elevations, some wells have declining water levels. With population growth expected for northeastern Wisconsin, additional groundwater abstraction from the confined sandstone aquifer near the southern cone would put greater strain on a system where some but not all wells are showing declines in water levels.

\section{Conclusions}

This article reviews the history of groundwater use in a confined sandstone aquifer in northeastern Wisconsin, USA over more than a century. In the recently established Northeast GMA, two well-developed cones of depression result from pumping localized in two urban areas. Water levels in the southern "Fox Cities" cone of depression have decreased steadily for decades. In contrast, water levels in the northern "central Brown County" cone of depression have varied significantly in response to two cycles of population growth, followed by transitions from groundwater to surface water supply sources.

As of 2016, the northern portion of the Northeast GMA is considered to be in a sustainable condition, with steady or rising water levels that have recovered as much as $70 \mathrm{~m}$ in the past decade. In contrast, the southern region of the Northeast GMA exhibits a somewhat different set of conditions. While water levels in some wells are steady, others show slow declines, which will likely be exacerbated by continued population growth.

Supplementary Materials: The following are available online at www.mdpi.com/2076-3263/7/1/11/s1, File S1: Complete set of historical contour maps for the Northeast GMA. File S2: Selected hydrographs for municipal and observation wells in the Northeast GMA. File S3: Stratigraphic column and table showing wells in central Brown County with dewatered conditions since 2005. File S4: Water Level Data for selected municipal wells in the Northeast GMA. File S5: Water Level Data used to construct contour maps for 1990 to 2015.

Acknowledgments: We would like to thank the Wisconsin Department of Natural Resources for funding a portion of this project through the University of Wisconsin Water Resources Institute (Project numbers PRJ16FE and PRJ16BW). Additional support of this project (exploration wells) came from the United States Geologic Survey STATEMAP Program (grant number 10HQPA0003) and the Wisconsin Geologic and Natural History Survey. We also thank the numerous municipal and private high capacity well owners/operators who supplied pumping data and water level data for the early portion of this project. Nancy Quirk and Tom Landwehr (Green Bay Water Utility) allowed extensive access to historical paper records for the city's wells. Dave Vaclavik offered valuable insight into the CBCWA. We also thank Wisconsin DNR personnel Robert Smail, Wendy Anderson, and Dave Johnson for assistance with gathering additional water level and pumping data. Benjamin Cruz-Uribe provided important historical insight into the politics of the Northeast GMA and provided useful comments. Kevin Fermanich and Chris Houghton aided with GIS questions. Funding was not obtained to cover costs to publish in open access. We also thank the two anonymous reviewers for their comments on improving the manuscript.

Author Contributions: David Hart and John Luczaj developed the study design, obtained funding, and participated in fieldwork. Julie Maas collected water level and pumping data for 2004 through early 2009, and contributed to fieldwork while completing a Master's thesis. Jonathan Odekirk compiled water level and pumping data for 2009 through 2015 and participated in GIS mapping of the potentiometric surface as part of an unpublished undergraduate senior thesis. John Luczaj collected additional data on water levels and pumping and wrote the majority of the final manuscript. All authors contributed to data interpretation and final editing.

Conflicts of Interest: The authors declare no conflict of interest. The founding sponsors had no role in the design of the study; in the collection, analyses, or interpretation of data; in the writing of the manuscript, or in the decision to publish the results. 


\section{Abbreviations}

The following abbreviations are used in this manuscript:

$\begin{array}{ll}\text { CBCWA } & \text { Central Brown County Water Authority } \\ \text { GBWU } & \text { Green Bay Water Utility } \\ \text { GMA } & \text { Groundwater Management Area } \\ \text { ML } & \text { Megaliters (millions of liters) } \\ \text { USEPA } & \text { United States Environmental Protection Agency } \\ \text { USGS } & \text { United States Geological Survey } \\ \text { SWL } & \text { Static Water Levels } \\ \text { WDNR } & \text { Wisconsin Department of Natural Resources } \\ \text { WGNHS } & \text { Wisconsin Geological \& Natural History Survey } \\ \text { WUWN } & \text { Wisconsin Unique Well Number }\end{array}$

\section{References}

1. Aeschbach-Hertig, W.; Gleeson, T. Regional strategies for the accelerating global problem of groundwater depletion. Nat. Geosci. 2012, 5, 853-861. [CrossRef]

2. World Water Assessment Programme. The United Nations World Water Development Report 4: Managing Water under Uncertainty and Risk. Report No. 978-92-3-104235-5, 2012, 407 (UNESCO, 2012). Available online: http:/ / www.unesco.org/new/fileadmin/MULTIMEDIA/HQ/SC/pdf/WWDR4\%20Volume\% 201-Managing\%20Water\%20under\%20Uncertainty\%20and\%20Risk.pdf (accessed on 9 January 2017).

3. Hayashi, T.; Tokunaga, T.; Aichi, M.; Shimada, J.; Taniguchi, M. Effects of human activities and urbanization on groundwater environments: An example from the aquifer system of Tokyo and the surrounding area. Sci. Total Environ. 2009, 407, 3165-3172. [CrossRef] [PubMed]

4. Visocky, A.P. Water-Level Trends and Pumpage in the Deep Bedrock Aquifers in the Chicago Region, 1991-1995; Illinois State Water Survey, Information Circular 182; Illinois State Water Survey: Champaign, IL, USA, 1997; p. 45. Available online: http://www.isws.illinois.edu/pubdoc/C/ISWSC-182.pdf (accessed on 9 January 2017).

5. Luczaj, J.; Masarik, K. Groundwater quantity and quality issues in a water-rich region: Examples from Wisconsin, USA. Resources 2015, 4, 323-357. [CrossRef]

6. Wisconsin Department of Natural Resources (WDNR). Wisconsin Water Use: 2013 Withdrawal Summary; Wisconsin Department of Natural Resources Water Use Section: Madison, WI, USA, 2014. Available online: http://dnr.wi.gov/topic/WaterUse/documents/WithdrawalReportDetail.pdf (accessed on 6 December 2016).

7. Buchwald, C.A. Water Use in Wisconsin. United States Geological Survey Open File Report, 2009-1076; 2005; p. 74. Available online: https://pubs.usgs.gov/of/2009/1076/pdf/ofr20091076.pdf (accessed on 27 February 2017).

8. Smail, R.A.; Wisconsin Department of Natural Resources, Madison, WI, USA. Personal communication regarding groundwater use in Wisconsin, 13 October 2014.

9. Erb, K.; Ronk, E.; Koundinya, V.; Luczaj, J. Groundwater Quality Changes in a Karst Aquifer of Northeastern Wisconsin, USA: Reduction of Brown Water Incidence and Bacterial Contamination Resulting from Implementation of Regional Task Force Recommendations. Resources 2015, 4, 655-672. [CrossRef]

10. Andren, A. Groundwater Drawdown. Wisconsin Water Resources Institute, p. 2. Available online: http: / /aqua.wisc.edu/publications/pdfs/GroundwaterDrawdown.pdf (accessed on 14 December 2016).

11. Kananen, C.; Luczaj, J.A. Drawdown of the Potentiometric Surface in the Cambrian-Ordovician Aquifer in Marinette County, Wisconsin. In Proceedings of the American Water Resources Association-Wisconsin Section, 39th Annual Meeting, Oconomowoc, WI, USA, 5-6 March 2015; Available online: http:/ / state.awra. org/wisconsin/2015meeting/AWRAProgram2015.pdf (accessed on 14 December 2016).

12. Weidman, S.; Schultz, A.R. The Underground and Surface Water Supplies of Wisconsin; Wisconsin Geological and Natural History Survey: Madison, WI, USA, 1915.

13. Knowles, D.B. Ground-Water Conditions in the Green Bay Area Wisconsin, 1950-1960. United States Geological Survey Water-Supply Paper, 1669-J, 1964, 37p. Available online: https:/ /pubs.usgs.gov/wsp/ $1669 j$ /report.pdf (accessed on 1 January 2017). 
14. Drescher, W.J. Ground-Water Conditions in Artesian Aquifers in Brown County Wisconsin; United States Geological Survey Water-Supply Paper 1190; USGS: Washington, DC, USA, 1953; p. 60.

15. LeRoux, E.F. Geology and Ground-Water Resources of Outagamie County Wisconsin; United States Geological Survey Water-Supply Paper 1421; USGS: Washington, DC, USA, 1957; p. 57.

16. Krohelski, J.T. Hydrogeology and Ground-Water Use and Quality, Brown County, Wisconsin; Wisconsin Geological and Natural History Survey: Madison, WI, USA, 1986; Volume 57, pp. 1-42.

17. Batten, W.G.; Bradbury, K.R. Regional Groundwater Flow Systems between the Wolf and Fox Rivers near Green Bay, Wisconsin; Wisconsin Geological and Natural History Survey, Information Circular 75; WGNHS: Madison, WI, USA, 1996; pp. 1-28.

18. Conlon, T.D. Hydrogeology and Simulation of Ground-Water Flow in the Sandstone Aquifer, Northeastern Wisconsin: U.S. Geological Survey Water-Resources Investigations Report 97-4096; USGS: Washington, DC, USA, 1998; p. 60.

19. Emmons, P.J. An Evaluation of the Bedrock Aquifer System in Northeastern Wisconsin; United States Geological Survey Water-Resources Investigations Report 85-4199; USGS: Washington, DC, USA, 1987; p. 48.

20. Walker, J.F.; Daad, D.A.; Krohelski, J.T. Optimization of Ground-Water Withdrawal in the Lower Fox River Communities, Wisconsin; United States Geological Survey Water-Resources Investigations Report 97-4218; USGS: Washington, DC, USA, 1998; p. 24.

21. Feinstein, D.T.; Hunt, R.J.; Reeves, H.W. Regional Groundwater-Flow Model of the Lake Michigan Basin in Support of Great Lakes Basin Water Availability and Use Studies: U.S. Geological Survey Scientific Investigations Report 2010-5109; USGS: Washington, DC, USA, 2010; p. 379.

22. Luczaj, J.A. Preliminary Geologic Map of the Buried Bedrock Surface, Brown County, Wisconsin. Wisconsin Geological and Natural History Survey Open File Report. 2011. WOFR2011-02, 1:100000 Scale Map Sheet. Available online: https://wgnhs.uwex.edu/pubs/download_wofr201102/ (accessed on 6 December 2016).

23. Brown, B.A. Preliminary Bedrock Geologic Map of Outagamie County, Wisconsin. Wisconsin Geological and Natural History Survey Open File Report. 2005. WOFR2005-02, 1:100000 Scale Map Sheet. Available online: http:/ /wgnhs.uwex.edu/pubs/download_wofr200502/ (accessed on 16 January 2017).

24. Luczaj, J.A. Geology of the Niagara escarpment in Wisconsin. Geosci. Wis. 2013, 22, 1-34.

25. Luczaj, J.A.; Hart, D.J. Drawdown in the northeast Groundwater Management Area (Brown, Outagamie, and Calumet Counties, WI); WDNR: Madison, WI, USA, 2009. Available online: http://wgnhs.uwex.edu/pubs/ wofr200904/ (accessed on 6 December 2016).

26. Maas, J.C. Drawdown, Recovery, and Hydrostratigraphy in Wisconsin's Northeast Groundwater Management Area (Brown, Outagamie, and Calumet Counties). Master's Thesis, University of Wisconsin, Green Bay, WI, USA, 2009.

27. Grundl, T.; Magnusson, N.; Brennwald, M.S.; Kipfer, R. Mechanisms of subglacial groundwater recharge as derived from noble gas, ${ }^{14} \mathrm{C}$, and stable isotopic data. Earth Planet. Sci. Lett. 2013, 369-370, 78-85. [CrossRef]

28. Baeten, J.B. Spatial Distribution and Source Identification of Dissolved Strontium in Eastern Wisconsin's Cambrian-Ordovician Aquifers. Master's Thesis, University of Wisconsin-Green Bay, Green Bay, WI, USA, 2015.

29. Hamby, A.; Luczaj, J.; Baeten, J. Exploring the Significance of Faults and Fractures in the Confined Aquifer in Northeastern Wisconsin (Brown and Outagamie Counties): Insights from Stable Isotope Patterns. In Proceedings of the American Water Resources Association-Wisconsin Section, 39th Annual Meeting, Oconomowoc, WI, USA, 5-6 March 2015. Available online: http:/ / state.awra.org/wisconsin/2015meeting/ AWRAProgram2015.pdf (accessed on 16 January 2017).

30. Wisconsin State Legislature. 2003 WISCONSIN ACT 310. 281.34 Groundwater Withdrawals (9). Available online: https:/ / docs.legis.wisconsin.gov/2003/related/acts/310 (accessed on 14 December 2016).

31. NOAA-National Weather Service, Index of Climate Images for Wisconsin. Available online: http://www. crh.noaa.gov/images/mkx/climate/ (accessed on 6 December 2016).

32. United States Census Bureau. United States Census-2010. Available online: http://www.census.gov/ 2010census/data/ (accessed on 6 December 2016).

33. Need, E.A. Pleistocene Geology of Brown County, Wisconsin; Wisconsin Geological and Natural History Survey Information Circular 48; WGNHS: Madison, WI, USA, 1985; p. 19. 
34. Moeller, C.A.; Hooyer, T.S.; Batten, W.G. Investigating recharge to bedrock aquifers through fine grained glacial deposits in east-central Wisconsin, Van Straten property, Outagamie County. In Late-Glacial History of East-Central Wisconsin. Wisconsin Geological and Natural History Survey Open File Report 2007-1; Hooyer, T.S., Ed.; WGNHS: Madison, WI, USA, 2007; pp. 21-26.

35. Luczaj, J.A.; McIntire, M.; Olson Hunt, M.J. Geochemical characterization of Trace MVT mineralization in Paleozoic Sedimentary Rocks of Northeastern Wisconsin, USA. Geosciences 2016, 6, 29. [CrossRef]

36. Mai, H.; Dott, R.H., Jr. A Subsurface Study of the St. Peter Sandstone in Southern and Eastern Wisconsin; Wisconsin Geological and Natural History Survey, Information Circular IC-47; WGNHS: Madison, WI, USA, 1985 ; p. 26.

37. Syverson, K.M.; Clayton, L.; Attig, J.W.; Mickelson, D.M. Lexicon of Pleistocene Stratigraphic Units of Wisconsin; Technical Report; Wisconsin Geological and Natural History Survey: Madison, WI, USA, 2011; pp. 1-180.

38. Mudrey, M.G.; Brown, B.A.; Greenberg, J.K. Bedrock Geologic Map of Wisconsin, 1:1,000,000 Scale Map Sheet. University of Wisconsin-Extension; Wisconsin Geological and Natural History Survey: Madison, WI, USA, 1982.

39. Smail, R.A.; Wisconsin Department of Natural Resources, Madison, WI, USA. Personal Communication regarding pumping rates for municipal wells in Wisconsin, 22 December 2015.

40. Wisconsin Department of Natural Resources. Wisconsin Well Construction Reports Plus Other Related Files; Filemaker Pro Database on Compact Disc; WDNR: Madison, WI, USA, 2016.

41. United States Geological Survey. USGS Groundwater Watch, Active Groundwater Level Network. Available online: https:/ / groundwaterwatch.usgs.gov/default.asp (accessed on 16 January 2017).

42. Burch, S.L. A Comparison of Potentiometric Surfaces for the Cambrian-Ordovician Aquifers of Northeastern Illinois, 2000 and 2007; Illinois State Water Survey Institute of Natural Resource Sustainability; University of Illinois at Urbana-Champaign Data/Case Study 2008-04: Champaign, IL, USA, 2008; p. 49.

43. Smail, R.A. Wisconsin Department of Natural Resources, Madison, WI, USA. Personal Communication on water levels in municipal wells in Wisconsin, 22 March 2016.

44. Smail, R.A. Wisconsin Department of Natural Resources, Madison, WI, USA. Personal Communication on water levels in municipal wells in Wisconsin, 20 September 2016.

45. Green Bay Press Gazette. Mayor Candidates Give Views on Water Question, 3 March 1955.

46. Cruz-Uribe, B. University of Wisconsin-Green Bay, Green Bay, WI, USA. Personal Communication regarding historical water use in Green Bay, 8 June 2009.

47. Judge, Brown, J. Denning and another $v$. City of Green Bay and others. Wisconsin Supreme Court Ruling, 8 November 1955. 271 Wis.230; 72 N.W.2d 730; 1955 Wisc. Lexis 326. Available online: http:/ law.justia. com/cases/wisconsin/supreme-court/1955/271-wis-230-4.html (accessed on 4 March 2017).

48. Donohue \& Associates, Inc. Letter to Brown County Planning Commission regarding effects of 10 Mgal./day pumping by the City of Green Bay, 1 April 1977.

49. Central Brown County Water Authority. History of the CBCWA. Available online: http://www.cbcwa.com/ history.html (accessed on 16 January 2017).

50. Thornburg, K.; Sahai, N. Arsenic occurrence, mobility, and retardation in sandstone and dolomite formations of the Fox River Valley, Eastern Wisconsin. Environ. Sci. Technol. 2004, 38, 5087-5094. [CrossRef] [PubMed]

51. Burkel, R.S.; Stoll, R.C. Naturally occurring arsenic in sandstone aquifer water supply wells of Northeastern Wisconsin. Groundw. Monit. Remediat. 1999, 19, 114-121. [CrossRef]

52. Egan, D. Water fight anything but neighborly; Dueling pipelines show urban-suburban mistrust. Milwaukee Journal Sentinel, 11 February 2006.

53. Vaclavik, D.; Central Brown County Water Authority, Green Bay, WI, USA. Personal Communication, 10 January 2017.

54. Morris, B.L.; Lawrence, A.R.L.; Chilton, P.J.C.; Adams, B.; Calow, R.C.; Klinck, B.A. Groundwater and Its Susceptibility to Degradation: A Global Assessment of the Problem and Options for Management; Early Warning and Assessment Report Series, RS. 03-3; UN Environment Programme: Nairobi, Kenya, 2003.

55. Luczaj, J.A. The largest flowing artesian well in the state of Wisconsin is (sometimes) an abandoned deep quarry. In Proceedings of the American Water Resources Association-Wisconsin Section, 38th Annual Meeting, Wisconsin Dells, WI, USA, 13-14 March 2014; Available online: http:/ / state.awra.org/wisconsin/ 2014meeting/Session3A4Luczaj.pdf (accessed on 6 December 2016).

56. Ferris, G.; Northeast Asphalt, Inc., Greenville, WI, USA. Personal communication, 15 June 2016. 
57. Anderson, D.; Vincent, Urban, Walker, \& Associates, Green Bay, WI, USA. Personal communication, 13 July 2016.

58. Freiburg, J.T.; Fouke, B.W.; Lasemi, Z. New Insights on Upper Mississippi Valley Mineralization Based on Solution Cavities in the Ordovician Galena Group at the Conco Mine, North Aurora, Illinois, USA; Circular 581; Illinois State Geological Survey: Champaign, IL, USA, 2012.

59. O’Rourke, J. Personal communication, 11 January 2012.

60. Roork, D. Personal communication, 4 August 2015.

61. Brown County Government. Brown County Register of Deeds Plat Book, Greene and Vroman's Subdivision No. 1; Brown County Government (Wisconsin): Green Bay, WI, USA, 1899.

62. Anderson, W. Wisconsin Department of Natural Resources, Madison, WI, USA. Personal communication, 3 January 2017.

63. Gotkowitz, M.B.; Schreiber, M.S.; Simo, J.A. Effects of water use on arsenic release to well water in a confined aquifer. Ground Water 2004, 42, 568-575. [CrossRef] [PubMed]

64. Luczaj, J.A. Detection and Evaluation of an Inadvertent Cross-Connection of a Water Supply Pipeline to a Municipal Backup Well: A Cautionary Case Study of Heavy Metals Release. In Proceedings of the American Water Works Association-Wisconsin Section Meeting, Plover, WI, USA, 22 February 2017.

65. Hamby, A. The Effects of Faults and Changing Water Levels on Confined Aquifer Water Chemistry in Northeastern Wisconsin. Ongoing Master's Thesis, University of Wisconsin, Green Bay, WI, USA. (unpublished).

(C) 2017 by the authors. Licensee MDPI, Basel, Switzerland. This article is an open access article distributed under the terms and conditions of the Creative Commons Attribution (CC BY) license (http:/ / creativecommons.org/licenses/by/4.0/). 